\title{
Território usado, saúde indígena e Covid-19 no Brasil
}

\author{
Pedro Queiroz \\ Beatriz Maia ${ }^{2}$
}

Resumo: O presente trabalho parte do questionamento de como os novos hábitos da pandemia da Covid-19 interferem no cotidiano da comunidade Santuário Sagrado dos Pajés, em Brasília. Para tanto, elenca-se como objetivo geral, apreender possíveis alterações nas dinâmicas territoriais da comunidade indígena no contexto da Covid-19. A metodologia da pesquisa envolveu levantamentos bibliográficos, saídas de campo realizadas à área durante os anos de 2019 e 2020 e aplicação de entrevista virtual semiestruturada com a liderança da comunidade indígena, visando apreender aspectos de suas dinâmicas territoriais e de acesso à saúde. Como resultado, a pesquisa aponta alterações nas dinâmicas ritualísticas e nos encontros cotidianos da comunidade, além de aspectos como a demarcação do território, apropriação das técnicas de informação e comunicação, e acesso a sistemas de saúde especializados, como favoráveis à contenção dos casos de Covid-19 naquele contexto territorial.

Palavras-chave: Território usado, território indígena, saúde indígena, Covid-19.

\section{Territorio usado, salud indígena y Covid-19 en Brasil}

Resumen: El presente trabajo parte de la pregunta de cómo los nuevos hábitos de la pandemia Covid-19 interfieren en el cotidiano de la comunidad Santuario Sagrado de los Pajés, en Brasilia. Por lo tanto, se lista como objetivo general, aprehender posibles cambios en las dinámicas territoriales de la comunidad indígena en el contexto de la Covid-19. La metodología de investigación envolvió levantamientos bibliográficos, viajes de campo realizados durante los años de 2019 y 2020, y aplicación de una entrevista virtual semiestructurada con el liderazgo de la comunidad indígena, buscando aprehender aspectos de sus dinámicas territoriales y de acceso a la salud. Como resultado, la investigación apunta cambios en las dinámicas ritualistas y en los encuentros diarios de la comunidad, además de aspectos como la demarcación del territorio, apropiación de técnicas de información y comunicación, y acceso a sistemas de salud específicos, como favorables a la contención de los casos Covid-19 en aquel contexto territorial.

Palabras Clave: Territorio usado, territorio indígena, salud indígena, Covid-19.

\section{Used territory, indigenous health and Covid-19 in Brazil}

Abstract: This paper wonders how the new habits of the Covid-19 pandemic interfere in the community of the Santuário Sagrado dos Pajés everyday life, in Brasília. Therefore, the aim objective is to identify the potential changes in the territorial dynamics of the indigenous community in the Covid-19 context. The research methodology involved bibliographic research, fieldwork conducted during the years 2019 and 2020, and the application of semi-structured virtual interviews with the indigenous community leadership, to learn aspects of their territorial dynamics and access to health care. As a result, the research points to changes in the community's ritualistic dynamics and daily encounters, besides aspects such as territory demarcation, information and communication techniques appropriation, and access to specialized health systems, as favorable to the containment of Covid-19 cases in that territorial context.

Keywords: Territory used, indigenous territory, indigenous health, Covid-19.

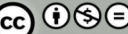

DOI: https://doi.org/10.26512/patryter.v4i8.35493

Como citar este artigo: Queiroz, P., \& Maia, B. (2021). Território usado, saúde indígena e Covid-19 no Brasil. PatryTer - Revista Latinoamericana e Caribenha de Geografia e Humanidades, 4(8), 38-57. DOI: https://doi.org/10.26512/patryter.v4i8.35493

Recebido: 09 de dezembro de 2020. Aceite: 12 de maio de 2021. Publicado: 01 de setembro de 2021.

${ }^{1}$ Geógrafo e mestrando em Geografia pela Universidade de Brasília, UnB. ORCID: https://orcid.org/0000-00034322-041X. E-mail: pedrothq@hotmail.com.

2 Graduada em Medicina pela Universidade Católica de Brasília, UCB. ORCID: https://orcid.org/0000-0001-86038955. E-mail: beatrizucbmed@gmail.com. 


\section{Introdução}

A ampla dispersão geográfica da Covid-19 refere-se, para além de aspectos relacionados à alta transmissibilidade da infecção, à maior fluidez territorial promovida por técnicas que facilitam o deslocamento e o transporte de pessoas. No território, e indissociável a este, a infecção se dispersa, acometendo em especial parcelas da sociedade historicamente vulnerabilizadas e apartadas do acesso à saúde, educação e renda, situação que vem se agravando com a pandemia. Nesse cenário dramático, encontram-se os povos indígenas, que segundo a Articulação dos Povos Indígenas do Brasil [APIB] (2020), apresentam um total de 163 povos afetados pela pandemia, 51.857 casos confirmados e 1.029 mortes causadas pela corona vírus.

Nesse cenário, o governo mantém a política de negligência aos povos indígenas. Visando ocupar, portanto, o vazio institucional deixado pelo Estado, não faltam exemplos de ações que se organizam em prol da defesa da vida indígena, como a APIB, o Conselho Indigenista Missionário [CIMT] e organizações que emergem das próprias comunidades, através da utilização das redes sociais como canais de difusão e obtenção de informações e planos para enfrentamento da Covid-19. Dentre as comunidades indígenas nesse panorama, encontrase o Santuário Sagrado dos Pajés, em Brasília, Distrito Federal.

Inserida em um contexto urbano que interfere em suas dinâmicas cotidianas, a comunidade não escapa aos efeitos nocivos que em diversos espectros recaem sobre os povos indígenas, como se apreende a partir de dados e estatísticas disponíveis em escala nacional. No entanto, este deve ser o primeiro momento da análise, a ser mantida no empírico, desnudando as complexas relações nas quais a comunidade indígena sob estudo está inserida, permitindo o entendimento de suas dinâmicas atuais.

Marcada por conflitos que se processam desde o território, envolvendo questões políticas e econômicas que interferem na delimitação do território indígena, a comunidade se apresenta inserida de forma "desigual" em um contexto no qual a pandemia da Covid-19 é uma das violências que a afetam, e contra a qual se movimentam. Dessa forma, frente a invisibilidade que recai sobre a comunidade, faz-se necessário a busca por referenciais teóricos-metodológicos que permitam o desnudamento das dinâmicas territoriais que se processam no Santuário dos Pajés.
Para tanto, o conceito proposto por Santos (1994) de território usado, operacionalizado desde o empírico, permite desnudar as dinâmicas territoriais que se desenvolvem na comunidade. Segundo Santos (2000, p. 104), o território usado diz respeito ao:

espaço de todos os homens, não importam suas diferenças; o espaço de todas as instituiçoes, não importa a sua força; o espaço de todas as empresas, não importa o seu poder. Esse é o espaço de todas as dimensões do acontecer, de todas as determinaçōes da totalidade social. É uma visão que incorpora o movimento do todo, permitindo enfrentar corretamente a análise.

A partir da compreensão dessas dinâmicas territoriais, desde os usos e funcionalidades que envolvem o território indígena, torna-se viável e necessário analisar e apreender possíveis alterações destas dinâmicas frente a pandemia da Covi-19. Assim, almejando a resolução do questionamento que embasa a pesquisa, fora realizada uma entrevista semiestruturada, aplicada virtualmente por meio de aplicativo de mensagens, tendo em vista o contexto da pandemia; ressalta-se que as trocas mantidas com a comunidade indígena nos últimos três anos, facilitaram o contato e a comunicação.

$\mathrm{Na}$ entrevista foram abordadas questões relacionadas: 1. à infraestrutura de saneamento básico e habitação - e às relações que nelas se estabelecem -; 2. ao comportamento no ambiente doméstico e o contato com os parentes; 3. ao cotidiano da comunidade, isto é, às dinâmicas internas e externas na qual está envolvida; 4. ao acesso a programas de atenção à saúde básica; 5. ao acesso à informação e comunicação relacionadas a Covid-19; 6. e à ocorrência ou não de casos positivos para Covid-19 na comunidade.

$\mathrm{O}$ que se apreende da entrevista aponta para uma situação delicada, dado o contexto urbano no qual a comunidade está inserida e os conflitos inerentes, mas que ao mesmo tempo possui aspectos favoráveis, como a demarcação do território, o contato com apoiadores e a Universidade de Brasília [UnB] e a disponibilidade de acesso a tecnologias de comunicação.

\section{Dispersão territorial da Covid-19 no Brasil}

A dispersão territorial da Covid-19, a despeito da alta transmissibilidade, é fomentada pelo o que Santos (2001, p. 23) define como sendo o "ápice do processo de internacionalização do 
mundo capitalista": a globalização. Este processo é marcado por "um sistema de técnicas presidido pelas técnicas da informação" e "resultado das ações que asseguram a emergência de um mercado dito global, responsável pelo essencial dos processos políticos atualmente eficazes" (Santos, 2001, p. 24); as técnicas possuem, antes de tudo, um caráter político, e sendo ambos elementos fundamentais para a compreensão da globalização, devem ser entendidos conforme sua indissociabilidade.

A história do capitalismo é composta por períodos, "pedaços de tempo marcados por certa coerência entre as suas variáveis significativas, que evoluem diferentemente, mas dentro de um sistema" (Santos, 2001, p. 33). Os períodos são antecedidos e sucedidos por crises, de forma que esse movimento sempre esteve presente na evolução do capitalismo. Entretanto, a globalização é marcada por uma superposição entre período e crise, na qual as crises são permanentes, sucessivas e estruturais (Santos, 2001). A pandemia da Covid-19 é síntese da dialógica período-crise da globalização, que como esta, se realiza em toda parte, mas se manifesta com maior intensidade em determinadas porções do território.

A necessidade de "criar condições para maior circulação dos homens, dos produtos, das mercadorias, do dinheiro, da informação, das ordens" (Santos \& Silveira, 2008, p. 261) carece de fluidez, fomentada pelos sistemas de objetos e sistemas de ações. Entretanto, a lógica globalizante agrava as diferenças e disparidades territoriais, promovendo os espaços "mais suscetíveis de participar de regularidades e de uma lógica obediente aos interesses das maiores empresas" (Santos \& Silveira, 2008, p. 264) - o que os autores definem como espaços luminosos, os quais acumulam densidades técnicas e informacionais, estando aptos a atrair conteúdo em capital, tecnologia e organização, se contrapondo, assim, aos espaços opacos.

A pandemia da Covid-19 inicia sua difusão em território nacional desde a região concentrada e outros espaços luminosos, "a partir do topo da pirâmide socioeconômica, entre as classes mais privilegiadas" (Alves, 2020, p. 29), tendo em vista a maior densidade de relações estabelecidas entre esses espaços (Guimarães, Catão, Martinuci, Pugliesi \& Matsumoto, 2020). Partindo da confirmação do primeiro caso de Covid-19 em fevereiro de 2020, os autores apontam para dispersão da doença a partir das principais metrópoles do país: São Paulo, Rio de Janeiro, Vitória, Brasília, Salvador, Recife, Fortaleza, Belém, Manaus, Curitiba, Florianópolis e Porto Alegre, em diálogo com a espacialização dos casos positivos elaborado por Hervé Théry (2020) (fig. 1), entre os meses de abril a março.

Guimarães et al (2020) ressaltam ainda a correlação positiva para óbitos por Covid-19 e áreas de aglomerados subanormais, expondo as vulnerabilidades territoriais do Brasil. De acordo com os autores, trata-se "de destacar a vulnerabilidade socioeconômica em que se encontram determinados grupos em detrimento de outros, considerando um país de dimensões continentais como o Brasil, com enorme diversidade sociocultural e desigualdades intrínsecas" (Guimarães et al, 2020, p. 132).

A interiorização da doença e sua dispersão, de acordo com Guimarães et al (2020) e conforme cartografia de Hervé Théry (2020) (fig. 2), processaram-se a partir dos dois principais modais de transporte nacional, as rodovias e as hidrovias, alcançando todo o território nacional, inclusive os espaços opacos. A esse respeito, é conhecido o comportamento do vírus nas áreas de maior precariedade, de forma que "fica claro que o vírus não é democrático, porque afeta de modo mais brutal tais grupos já mais fragilizados e que não dispõem de condições para o isolamento social" (Alves, 2020, p. 29).

Neste momento, o país possui a trágica marca de 484.235 óbitos (Painel Coronavírus, 2020), alcançando todos os estados e municípios da federação. $\mathrm{O}$ esforço metodológico empreendido por Guimarães et al (2020) para a compreensão geográfica da expressão da Covid-19 em território nacional permite o entendimento de que "a dinâmica espacial da Covid-19 se deu ancorada em estruturas territoriais já conhecidas pelos geógrafos" (Guimarães et al, 2020, p. 134), o que ressalta a relevância dessa ciência frente a pandemia, que extrapola "uma análise simplificada do espaço geométrico", de forma que as produções cartográficas sejam o ponto de partida para o raciocínio geográfico. Assim, de acordo com os autores, apreendem-se as interações entre as dinâmicas econômicas, traduzidas nas hierarquias territoriais, e as diversas feições geográficas zonais, reticulares e pontuais que a covid-19 assumiu ao se dispersar pelo território nacional. 
Figura 1 - Casos de Covid-19 em território nacional: meses de abril, maio e junho

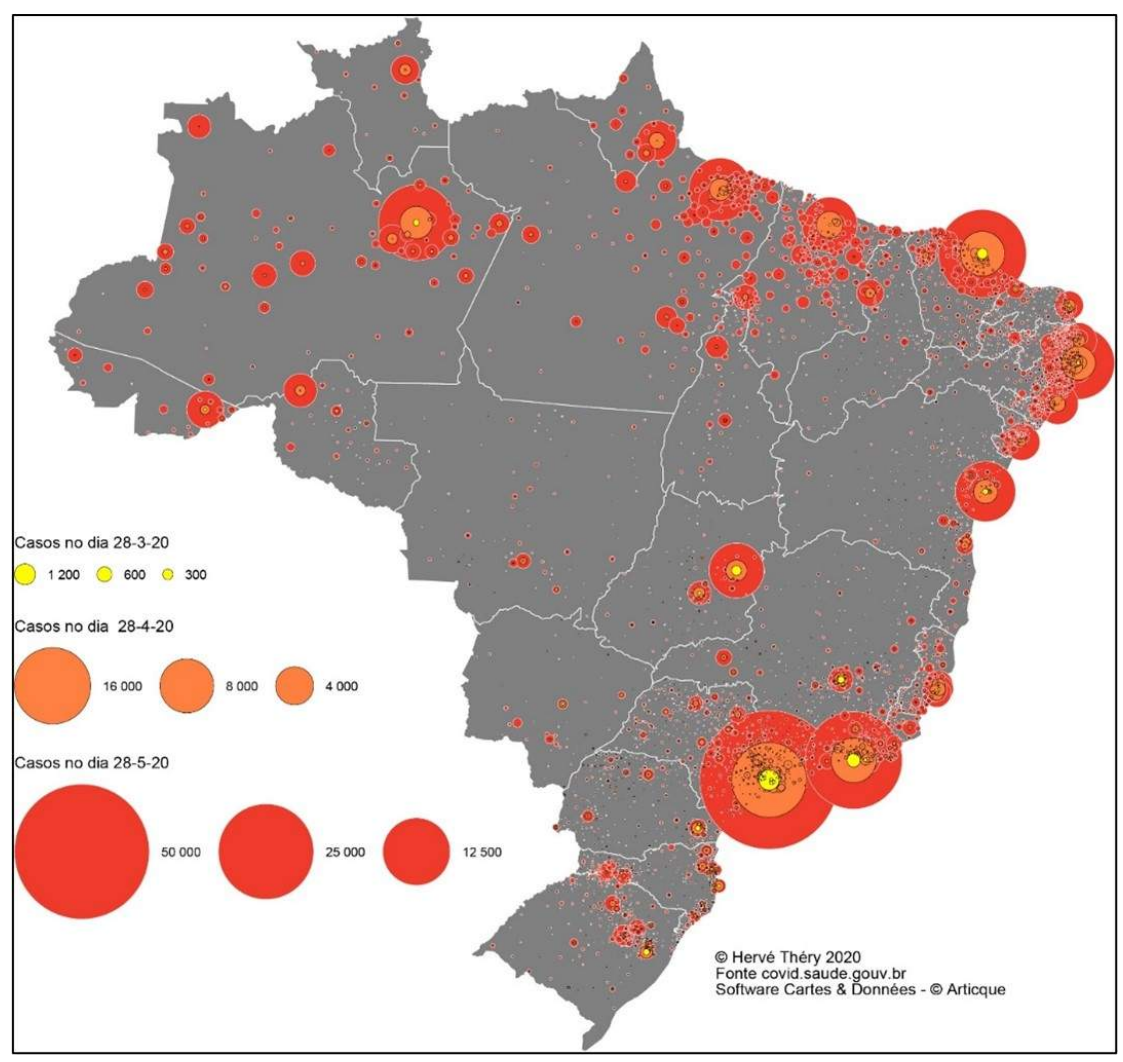

Fonte: Théry (2020, p. 3).

Figura 2 - Hidrovias, rodovias e casos de Covid-19 no Brasil

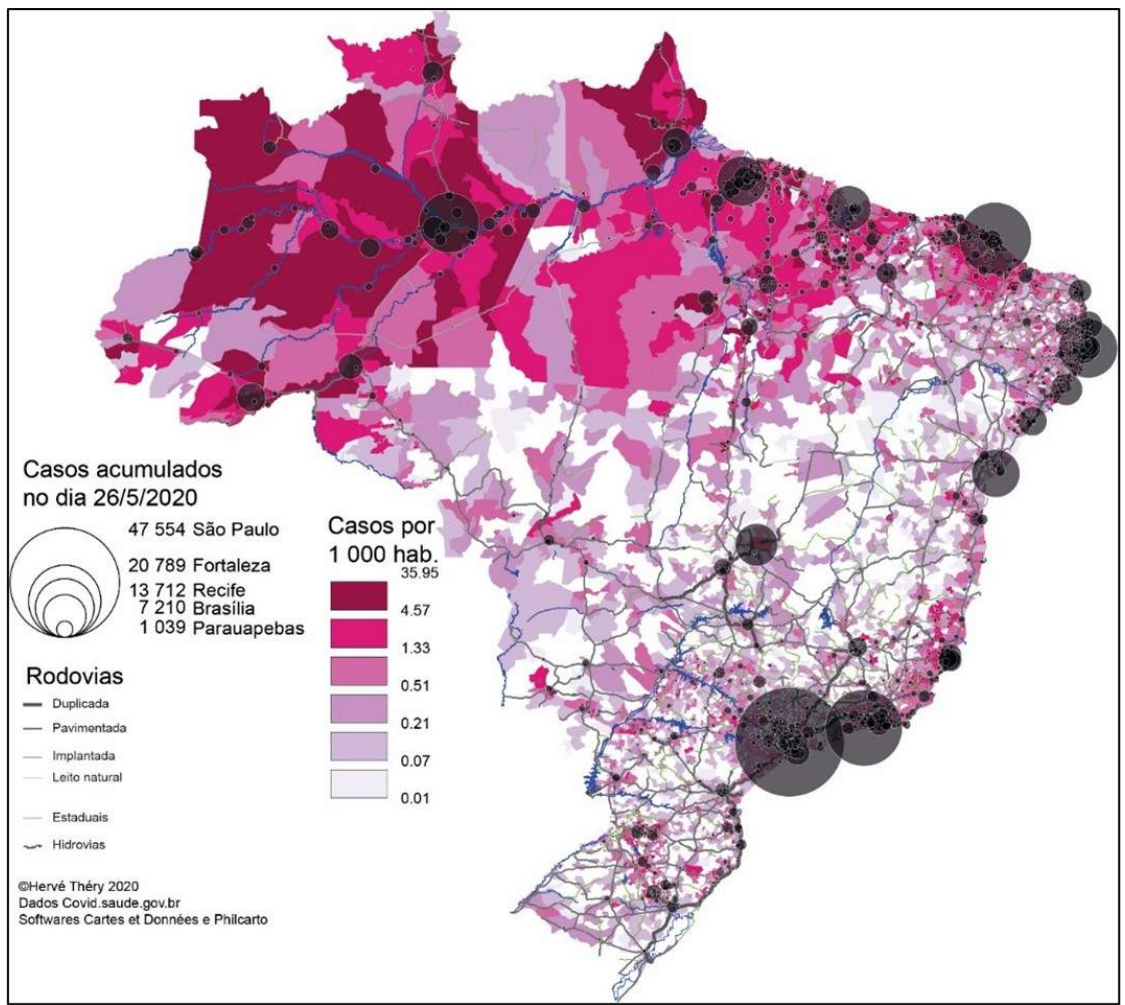

Fonte: Théry (2020, p. 3). 
No movimento de dispersão territorial, a doença alcança os povos e comunidades indígenas, de que acordo com Mondardo (2020, p. 82) "tornaram-se ainda mais vulneráveis pela precariedade de suas condições materiais de vida e da acentuação dos conflitos e ataques aos seus territórios originários". O avanço da pandemia sobre os povos indígenas representa mais uma expressão do histórico genocídio, reafirmando a importância de debates a respeito da posse do território originário e de sua segurança frente a ataques que desde o poder executivo estimulam a grilagem de terras, garimpo ilegal, desmatamentos e queimadas, o que no contexto da pandemia inviabiliza práticas de isolamento social e aprofundam a situação de vulnerabilidade (APIB, 2020).

O primeiro caso de contaminação indígena por Covid-19 ocorreu em 25 de março, no município Santo Antônio do Içá, através de um médico a serviço da Secretaria Especial de Saúde Indígena [SESAI]. Desde então os casos não pararam de aumentar e acometer povos de todo o país, em especial dos Estados do Amazonas (254 mortes), Mato Grosso (159 mortes) Roraima (126), Mato Grosso do Sul (114), Pará (107 mortes); o cenário atual aponta para um número desolador $\mathrm{e}$ expõem a necessidade de ações em prol da vida indígena: são 55417 casos confirmados, 163 povos afetados e 1104 indígenas mortos pela Covid-19 (APIB, 2020).

Do contexto nacional parte-se para a análise da experiência empírica representada pela comunidade indígena Santuário Sagrado dos Pajés, em Brasília, envolvida em um contexto urbano que interfere em seu território. A importância deste exercício permite apreender as especificidades dos fenômenos, apontando potenciais perspectivas de melhora da realidade; para tanto, que conheçamos um pouco do processo de formação da comunidade e do contexto urbano representado pelo bairro Noroeste.

\section{A formação do Santuário dos Pajés e a construção do bairro Noroeste}

O processo de formação e consolidação territorial da comunidade indígena Santuário Sagrado dos Pajés está relacionada aos movimentos migratórios cidade-campo no continente. A manutenção deste movimento é inerente a duração das condições de riscos e vulnerabilidades que afetam os povos e comunidades indígenas, tornando-os sujeitos a dinâmicas territoriais, como as promovidas pela urbanização e industrialização a partir de meados da década de 1950, momento de convergência dos esforços nacionais em prol da realização do Plano de Metas do governo de Juscelino Kubistchek, trazendo ideários desenvolvimentistas cuja expressão máxima seria Brasília, a nova capital da república.

A cidade pensada e planejada ainda carrega os desejos a favor da modernidade, que "daria corpo ao nacionalismo desenvolvimentista incorporado pela racionalidade industrial e urbanizadora do território brasileiro em totalidade, rompendo com regionalismos de gênese colonial" (Costa \& Steinke, 2014, p. 8). Entretanto, o cenário que se sucedeu à construção da cidade, aponta para uma Brasília que, a despeito das perspectivas propostas nos âmbitos teóricos e das ideias, perpetuou e favoreceu, desde uma semiótica tecnicista, racional e imersa em intencionalidades, o protagonismo econômico da região Sudeste, e que, ao invés de promover uma eficiência econômica e política a cada região do país, reafirmou um território que se integraria com vias à concentração espacial do capital, da indústria e do comando técnico e operacional do trabalho desde São Paulo (Costa \& Steinke, 2014).

O reforço das especializações produtivas do território fez-se sentir por todo o país. Nesse sentido, a região Nordeste se dispõe a oferta de produtos primários, do setor agrícola e de minério (Costa \& Steinke, 2014), além de suprir a demanda de mão-de-obra para a construção de Brasíliai. Ao reforçar a estrutura social, econômica e política da região Nordeste e as disparidades territoriais, tendo em vista a manutenção das desigualdades, Brasília expressa o caráter conservador que permeia seu âmago moderno, modernista e modernizante (Costa \& Alvarado, 2019).

Neste movimento, em meados de 1957, vindos de Águas Belas, Pernambuco, chegam a Brasília, Pedro e Maria Verissimo, seguidos por Antônio Inácio Severo (o cacique zumba), Jaime Ribeiro e Francisco Cajueiro, endossando o contingente populacional indígena migrante em Brasília (Brayner, 2013). Para estes, a migração não acarretou desterritorialização ou inviabilizou a manutenção de práticas sagradas ao povo Fulni-ô, uma vez que, durante as andanças no cerrado em busca de locais para exercerem seus saberes e fazer milenares, os indígenas identificaram uma parcela do território como ancestral, passando a produzi-lo de acordo com suas concepções. Segundo Oliveira, Pereira e Barreto (2011):

ainda que inicialmente não tenham estabelecido moradia permanente na área, ao passarem a 
frequentá-la com periodicidade para a prática de rituais religiosos, contribuiram de maneira prática e simbólica para a bumanização daquele espaço, adaptando-o gradualmente ao seu modo de vida. (Oliveira et al, 2011, p. 21)

Por volta de 1970, cerca de 27 indígenas Fulni-ô chegam a Brasília em "paus-de-arara", dentre eles o Pajê Santxiê, em busca de melhores condições de vida e trabalho, para fugir da fome e de epidemias, como a cólera, e em reação à tomada de terras indígenas pelo SPI, dando parte para igreja e fazendeiros não-indígenas, deixando aos indígenas as terras menos férteis - como consta em relatos de Santxiê em Oliveira et al (2011). Nessas "idas e vindas entre Brasília e Águas Belas, eles - Santxiê e aliados Fulni-ô - e outros indígenas, protagonizaram a constituição de uma rede de relações sociais para além-fronteiras étnicas e territoriais dos Fulni-ô, e mais próximas do poder central do país sediado na Capital Federal" (Oliveira et al, 2011, p. 21).

A presença da comunidade, amparada na ancestralidade identificada pelos primeiros Fulni-ô que vieram a Brasília, começa a ser questionada a partir do momento em que a área passa a ser cobiçada pelo mercado imobiliário da região, visando a construção de empreendimento habitacional de classe média alta/alta. Este empreendimento é o bairro Noroeste, cujas construção se inicia a partir 2008, após resolução de pendências referentes a licenças ambientais e jurídicas.

O Noroeste surge como um bairro conceito, de forma que as narrativas que circundam o empreendimento apostam no discurso "ecológico" e "sustentável" materializado na presença de placas para aproveitamento de energia solar, captação da água da chuva, sistema de coleta de resíduos a vácuo e redes de ciclovias, aplicadas com vias ao alcance da sustentabilidade. No entanto, como ressalta Rodrigues (2012, p. 22), "los discursos sobre el medio ambiente tienen la finalidad de permitir la continuidad de la producción de mercancias y garantizar la apropriación privada de las riquezas, reafirmando la ideología dominante". Portanto, as matrizes discursivas que emanam do bairro desconsideram a produção territorial originária, as relações sociais previamente estabelecidas e suas reais demandas. $\mathrm{O}$ empreendimento Noroeste surge impondo novas temporalidades e territorialidades, fomentando conflitos para com a comunidade indígena Santuário dos Pajés.
Desse breve esforço de síntese, apreende-se que o processo de formação e consolidação da comunidade indígena Santuário Sagrado dos Pajés remonta a uma ancestralidade que traz consigo aspectos por essência originários, processados sobre o território de forma que, fronteiras, limites ou mesmo a condição migrante não inviabilizam a produção territorial indígena e o exercício dessa ancestralidade, presentes nas dinâmicas sociais e na organização da comunidade, que serão analisados a seguir, embasados sob o conceito de território usado, com fins a uma apreensão totalizante das relações estabelecidas na área.

\section{Território usado: diversidade e singularidade de funções}

Levando-se em consideração a historicidade do espaço geográfico, a categoria de análise não se circunscreve ao território em si, mas ao território usado, de forma que, ao "definir qualquer espaço do território, deveremos levar em conta a interdependência e a inseparabilidade entre a materialidade, que inclui a natureza, e o seu uso, que inclui a ação humana, isto é, o trabalho e a política" (Santos, 2001, p. 247). Santos (2014) afirma que, por se tratar de uma noção, os usos do território carecem de constantes revisões históricas, sendo o empírico uma dimensão relevante neste procedimento, como apontam Costa e Scarlato (2019, p. 648): "lo empírico conlleva los fundamentos y las crisis de los fundamentos geográficos; crisis de la estructura interna de la Geografía, de su esencia, donde sus conceptos fundamentales se tornan vacilantes con el cambio del mundo".

A consideração do território usado, tido como sinônimo de espaço geográfico, perpassa a análise, de um lado, da fluidez virtual, "oferecida por objetos criados para facilitar essa fluidez e que são, cada vez mais, objetos técnicos" (Santos, 2014, p. 138) e de uma fluidez real, que vem das ações humanas, "cada vez mais ações informatizadas, ações normatizadas" (Santos, 2014, p. 138). Dessa realidade territorial emergem novos recortes: as horizontalidades e verticalidades, resultados da nova construção do espaço e do novo funcionamento do território (Santos, 2014).

Santos (2014, p. 139) define que as "horizontalidades serão o domínio da contiguidade territorial, enquanto as verticalidades seriam as formas e processos sociais". A apreensão totalizante desses recortes permite que se operacionalize a oposição entre o espaço banal, que é o espaço de 
todos, todo o espaço, e o espaço das redes, que justifica a expressão das verticalidades e que são constituintes de apenas uma parte do espaço e representam o espaço de alguns (Santos, 2014). Ressalta o autor que o território pode ser formado por lugares contíguos e lugares em redes, de forma que representam os mesmos lugares; isto é, como um palimpsesto, lugares formam espaços de redes e formam o espaço banal, "contendo simultaneamente funcionalizações diferentes, quiçá divergentes ou opostas" (Santos, 2014, p. 139).

O debate acerca do território, com vias a aprofundar o conhecimento desse aspecto da realidade total, não deve se limitar a mundialização ou globalização (Santos, 2014). Assim, é necessária a operacionalização das escalas de análise, das quais o empírico apresenta-se como um momento desta, permitindo a apreensão de detalhes e dinâmicas que, sob uma escala reificada, não tendem à totalidade espacial (Moore, 2018).

O trabalho de campo em geografia e a observação são oportunidades de legitimação teórica e de descobertas de novos fenômenos (Costa \& Scarlato, 2019), a partir do empírico e desde o lugar, o qual, segundo Santos (2014), é a sede de resistência da sociedade civil. Para tanto, faz-se necessária a revisão da realidade desde dentro, interrogando sua própria constituição neste momento histórico, e a indispensável insistência com vias ao "conhecimento sistemático da realidade, mediante o tratamento analítico desse seu aspecto fundamental que é o território (o território usado, o uso do território)" (Santos, 2014, p. 143).

A análise que se pretende realizar, remonta aos usos e funcionalidades díspares e singulares que se processam sobre o território que envolve o bairro Noroeste e a comunidade Santuário Sagrado dos Pajés. Por se constituir "como um todo complexo onde se tece uma trama de relações complementares e conflitantes" (Santos 2000, p. 104) e por permitir "pensar processualmente as relações estabelecidas entre o lugar, a formação socioespacial e o mundo" (Santos 2000, p. 105), o território usado se apresenta como potencial teórico-conceitual para a presente análise, permitindo uma perspectiva totalizante do território e promovendo a externalização do "mundo das sombras" dos usos e das funcionalidades territoriais da comunidade indígena em questão, cujas dinâmicas são inviabilizadas e sobrepostas pelo Mundo (entendido aqui como mercado), em desconsideração à ancestralidade de ocupação da área e da contemporaneidade da presença indígena.
As informações a respeito dos usos do território referentes ao Noroeste, foram levantadas em saída de campo ao bairro, com o objetivo de apreender as dinâmicas territoriais cotidianas e obter materiais iconográficos, captando um momento do movimento territorial. A localização do bairro (fig. 3) torna-se um atrativo para compradores e investidores do ramo imobiliário, pela ampla diversidade de serviços e até alguns atrativos de lazer dispostos ao longo da DF - 003, a Estrada Parque Indústria e Abastecimento [EPIA] e nas proximidades do setor Noroeste. Cita-se o Setor de Oficinas Norte [SOFN], as margens da EPIA, como um local de atividades de prestação de serviços automotivos, como oficinas mecânicas, distribuidoras de peças e postos de combustíveis, mas também outros estabelecimentos, como farmácias, algumas lanchonetes e restaurantes, além de uma rede de lojas de materiais de construção e afins. O fluxo virtual, promovido pela DF - 003, apresenta-se como promotor da localização destas atividades.

O atrativo de lazer fica a cargo do Parque Nacional de Brasília [PNB], mais conhecido pelos brasilienses como "Água Mineral". Fundado em 29 de novembro de 1961, com uma área de aproximadamente 42.389,01 hectares e sob gestão do Instituto Chico Mendes de Conservação da Biodiversidade [ICMBio], o parque possui uma diversidade de atrativos, como duas piscinas de água corrente e trilhas, que permitem proximidade com a variedade fitofisionômica da vegetação de cerrado e de sua fauna presentes na área do PNB.

$\mathrm{Na}$ saída da EPIA, em direção à via de acesso ao bairro Noroeste, mais infraestruturas de prestação de serviços que remetem, de um lado, à transnacionalização do território, tendo em vista a presença de quatro concessionárias de veículos automotivos, redes de shopping center, atacadões e hipermercados e uma rede de petshop, além de postos de gasolina; e de outro lado, a presença do Estado no ordenamento do território, materializada pela $2^{a}$ Delegacia de Polícia Civil e pelo Grupamento de Proteção Ambiental do Corpo de Bombeiros Militar do Distrito Federal [CBMDF].

O Noroeste fora pensado e planejado, e sua situação atual é de um bairro ainda em construção (fig. 4): as ciclovias ainda não respondem ao que fora estipulado e o Parque Burle Marx, que reforça os falsos preceitos ecológicos e sustentáveis do bairro, sendo um atrativo para a compra dos imóveis, não está concluído nem atende à população local. 
Figura 3 - Mapa de localização da área de estudo

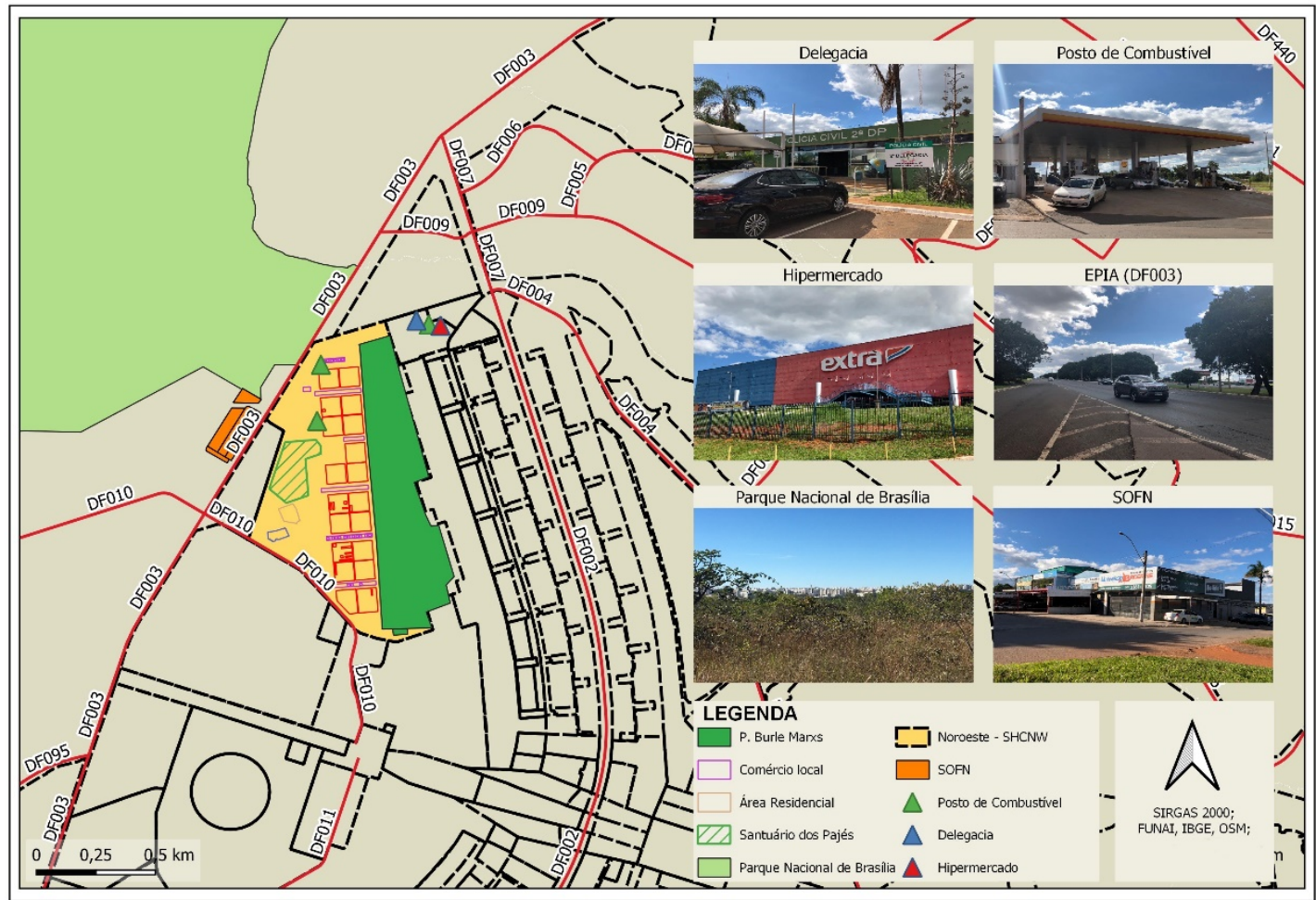

Fonte: elaboração própria, 2021.

Figura 4 - Ciclovia e visão parcial da área destina ao Parque Burle Marx

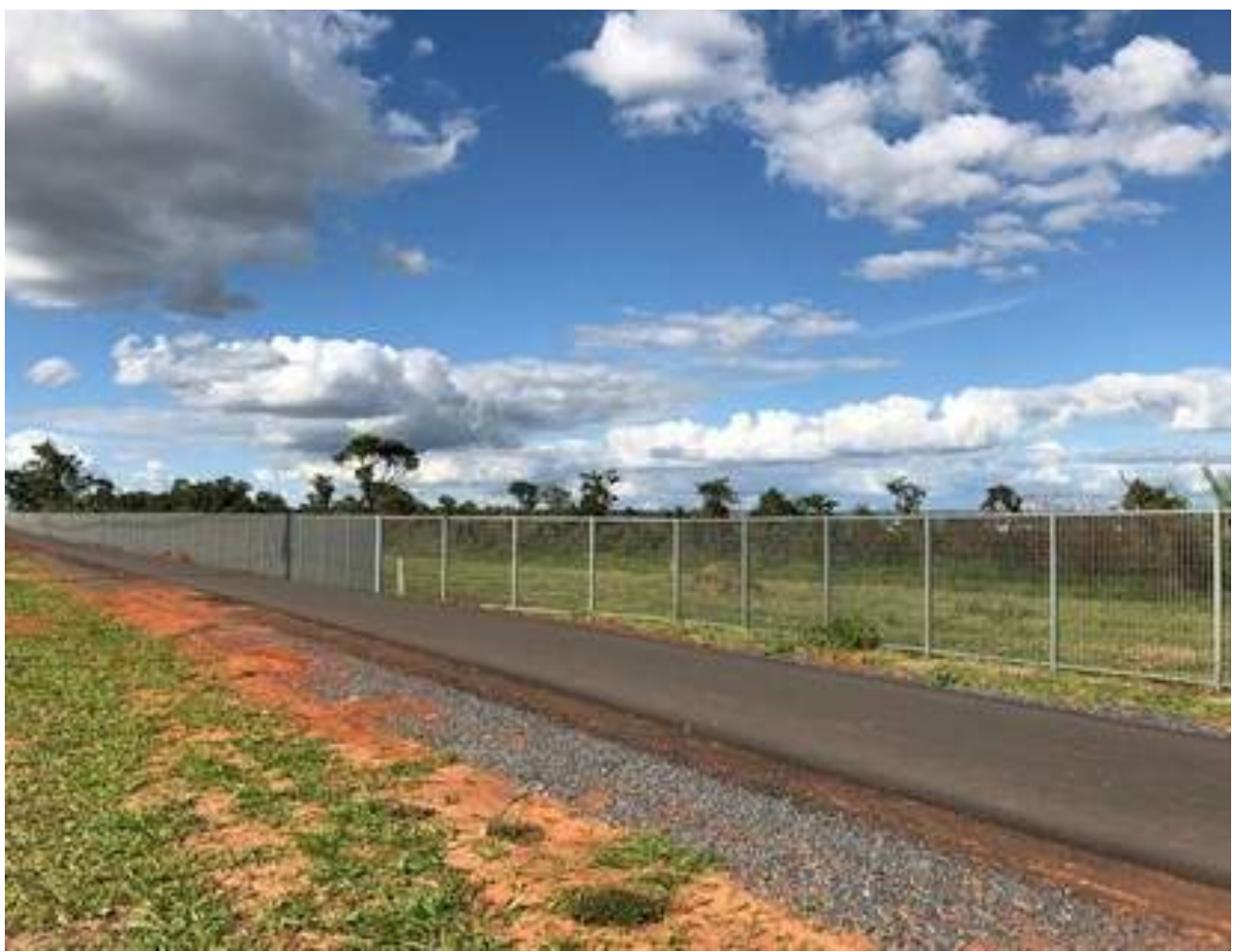

Fonte: acervo autores, 2020. 
Figura 5 - Quadra de comércio local 11/10

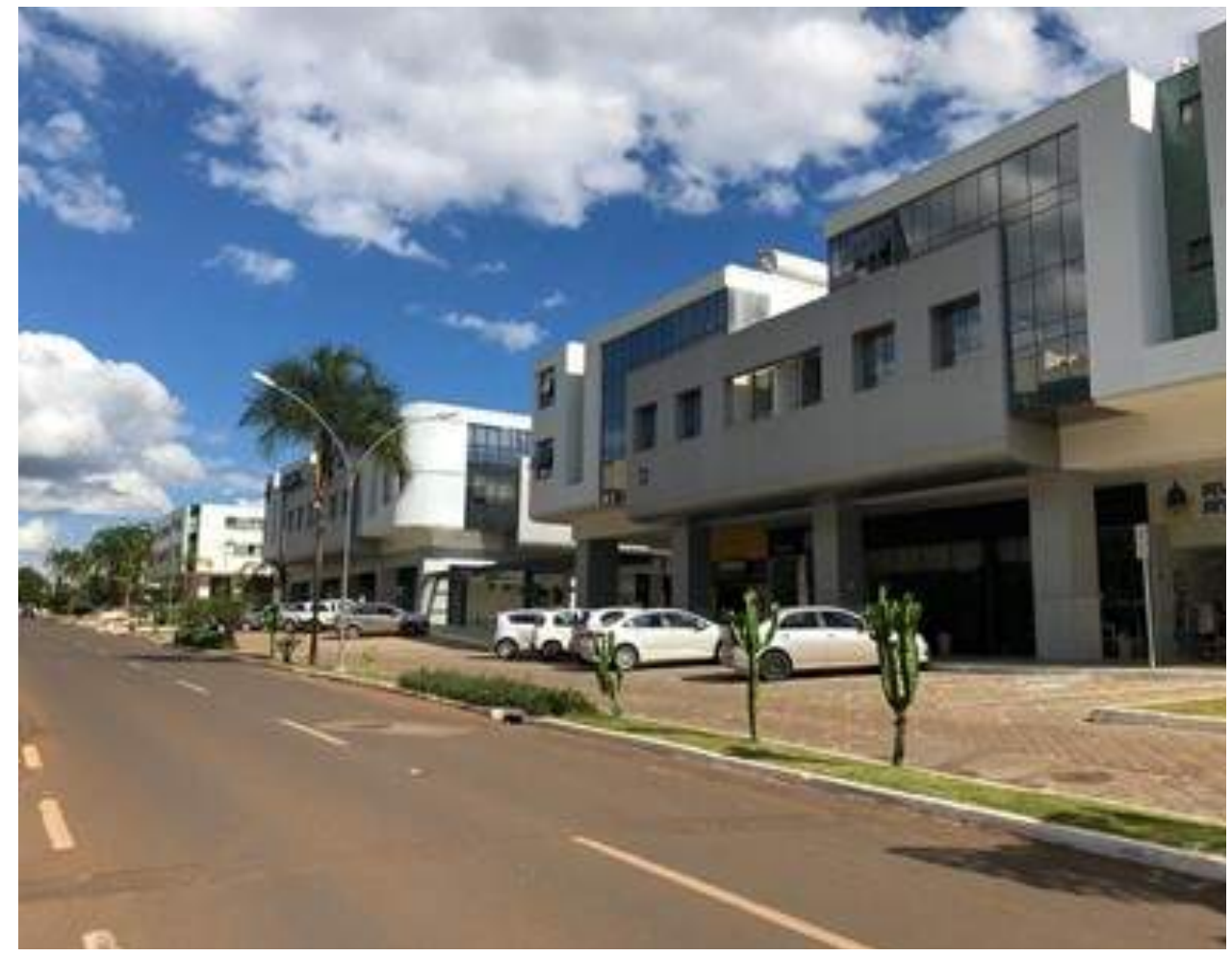

Fonte: acervo autores, 2020.

Figura 6 - Edifícios em construção no setor Noroeste

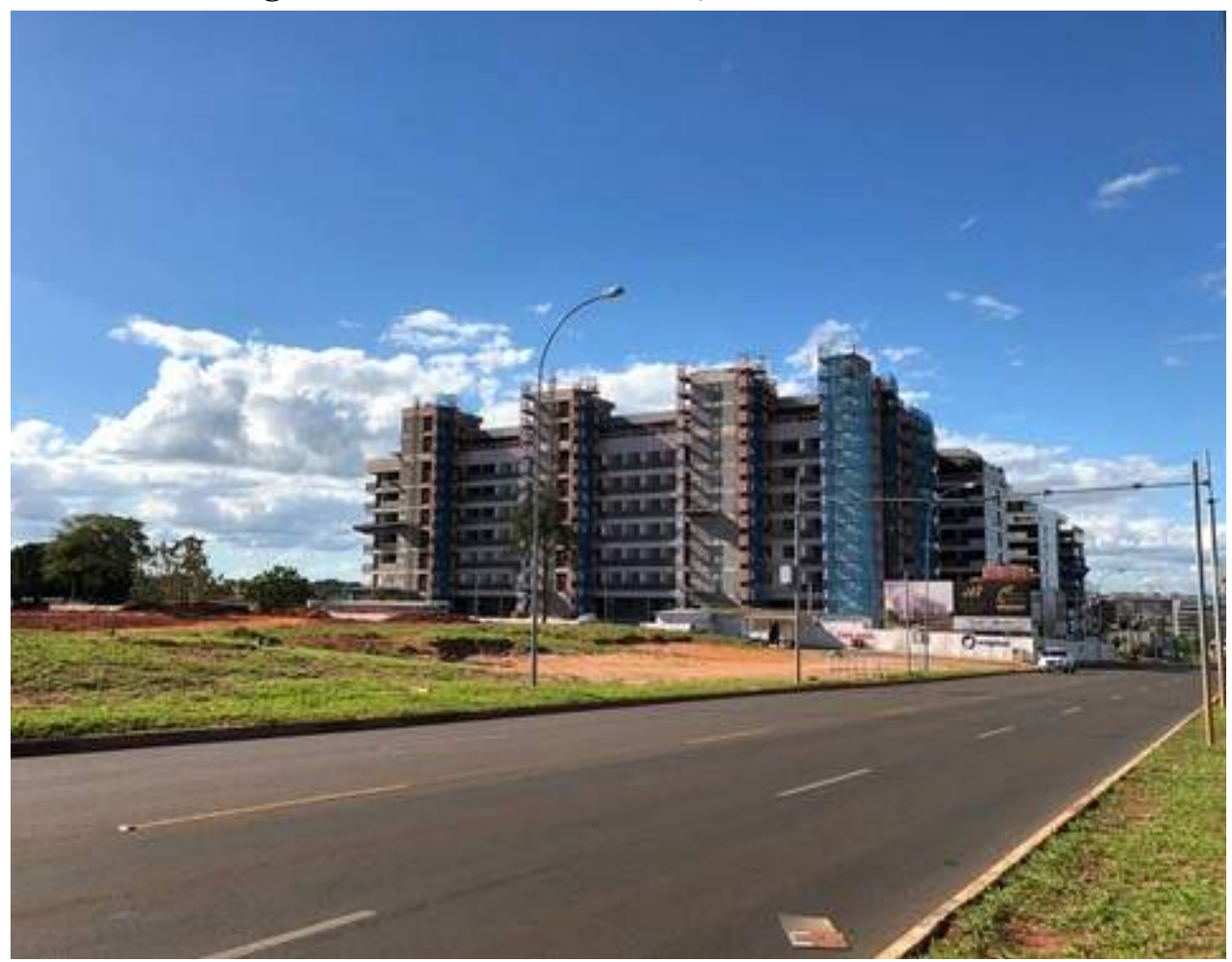

Fonte: acervo autores, 2020. 
As áreas de comércio local, segundo o planejamento urbano, serão dispostas em cinco áreas intercaladas entre os espaços residenciais. Destas cinco áreas de comércio, apenas uma, o "comércio local 11/10" (fig. 5), está plenamente construído e em utilização, contemplando serviços como padarias, restaurantes, farmácias, lojas de roupas, estúdios de pilates e laboratórios, por exemplo. Ressalta-se a dupla funcionalidade desses espaços comerciais, que congregam também moradias do tipo "kitnet" sobre as lojas e comércios. As demais áreas de comércio local ainda se encontram em fase de construção, sendo parte dessa paisagem em rápida transformação, imobiliárias de venda e aluguel desses espaços.

Os usos residenciais do bairro, em especial os de alto padrão, são os que estão em fase de construção mais acelerada. A ida a campo e a compreensão das dinâmicas territoriais que ali se processam desnudam a relevância e a preponderância dada a esses tipos de edificações, tendo em vista a incessante busca pelo lucro por parte dos agentes do mercado imobiliário da região. São as especulações imobiliárias e financeiras que fomentam o planejamento das projeções de prédios e suas construções (fig. 6).

Em prol do ócio e do entretenimento dos moradores do bairro e intercaladas às áreas residenciais e comerciais, estão as áreas de lazer, contendo uma variedade de objetos que permitem a realização de atividades e o encontro cotidiano dos moradores. Dentre esses objetos encontram-se as chamadas PEC [Ponto de Encontro Comunitário], quadras poliesportivas, parquinhos e praças, além de resquícios de áreas verdes dentre a imensidão das edificações em concreto. Ademais, o bairro conta, em seu ordenamento e disposição de infraestruturas territoriais, com duas subestações de tratamento de água da CAESB e redes de iluminação e sinalização das áreas que compõem o Noroeste.

A análise dos usos do território envolve sua totalidade, assim como remete a uma sobreposição desses usos desde o lugar. Nesse exercício, ressaltando a precedência de métodos e metodologias que respondam à análise desejada, que compreendamos, então, os usos e as funcionalidades do território processadas pela comunidade Santuário Sagrado dos Pajés, que resguarda em suas práticas cotidianas, expressões de saberes e fazeres milenares e uma práxis territorial originária, marcada pela indissociabilidade da interação entre o ser indígena e o território (a terra).

Essencialmente comunitário e horizontal, o território indígena em muito destoa de outras concepções territoriais, promovidas por uma dita humanidade que, nas palavras de Ailton Krenak (2019, p. 5), "vai se deslocando de maneira absoluta desse organismo Terra, vivendo numa abstração civilizatória que suprime a diversidade, nega a pluralidade das formas de vida, de existência e de hábitos". Afirma o autor que os indígenas são alguns dos "únicos núcleos que ainda consideram que precisam se manter agarrados à Terra" (Krenak, 2019, p. 5).

A análise seguinte emerge de reflexões e idas a campo ao Santuário dos Pajés durante o ano de 2019 em ocasiões variadas, permitindo a apreensão de aspectos referentes aos usos e funcionalidades do território, que compõem o presente estudo. Tais aspectos que emergem do território indígena, em consonância com a ancestralidade, envolvem práticas comunitárias como rituais sagrados, cultivo de hortas e práticas de reflorestamento da vegetação nativa, construção de edificações a partir da utilização de técnicas adaptadas ao cerrado, e produção e venda de artesanato local.

Os rituais sagrados realizados no Santuário dos Pajés representam momentos de encontro entre os indígenas da comunidade, parentes de outros povos e apoiadores, processados em espaços como a Casa de Reza e as Ocas das Crianças, das Mulheres e dos Homens. Nestes espaços se processam práticas ancestrais marcadas por manifestações de saberes-fazeres materiais-imateriais, indissociáveis entre si. As Ocas das Crianças e das Mulheres (fig. 7 e 8), durante os períodos de conflitos mais intensos entre a comunidade e os agentes do Mundo, foram queimadas e sua estrutura física suprimida, conquanto sua existência persista no âmbito do imaginário comunitário.

As edificações de adobe, aplicadas em construções como no tanque de peixes, nas antigas Ocas da Mulheres e das Crianças e na Oca dos Homens (que depois do ataque às demais, fora reelaborada, de forma a manter-se mais resistente a possíveis violências) suprem, respectivamente, as necessidades alimentares e espirituais da comunidade e reforçam sua interação com o território.

Essa interação se manifesta também na presença de três cemitérios indígenas. Um destes, hoje subposto à área destinada a usos residenciais no Setor Noroeste, ressaltando um aspecto claro da colonialidade expresso por esta pretensa modernidade; os outros dois cemitérios indígenas, por sua vez, estão localizados dentro da delimitação institucional do território, em locais próximos das 
Figura 7 - Local de antiga existência da Oca das Mulheres

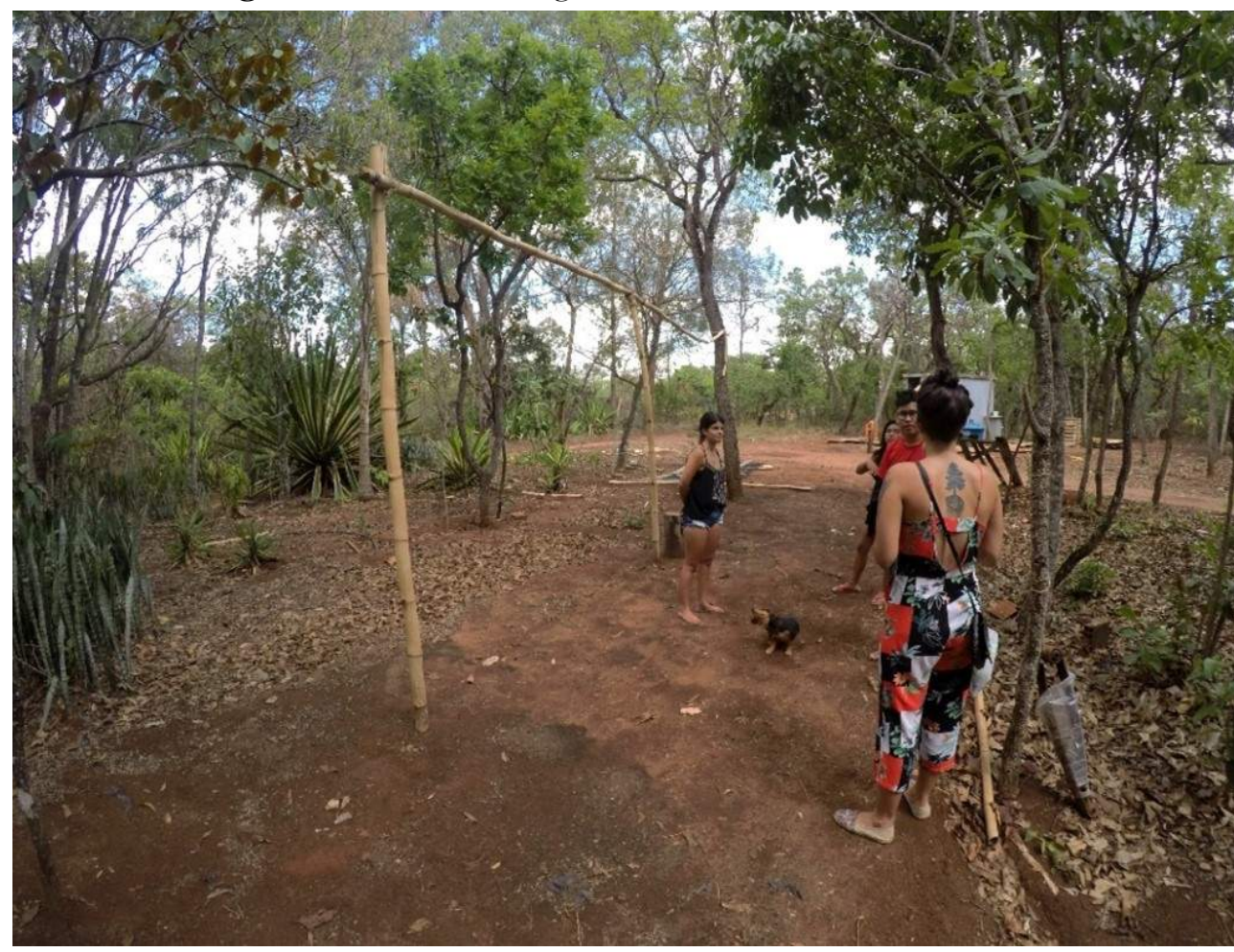

Fonte: acervo autores, 2020.

Figura 8 - Local da antiga existência da Oca das Crianças

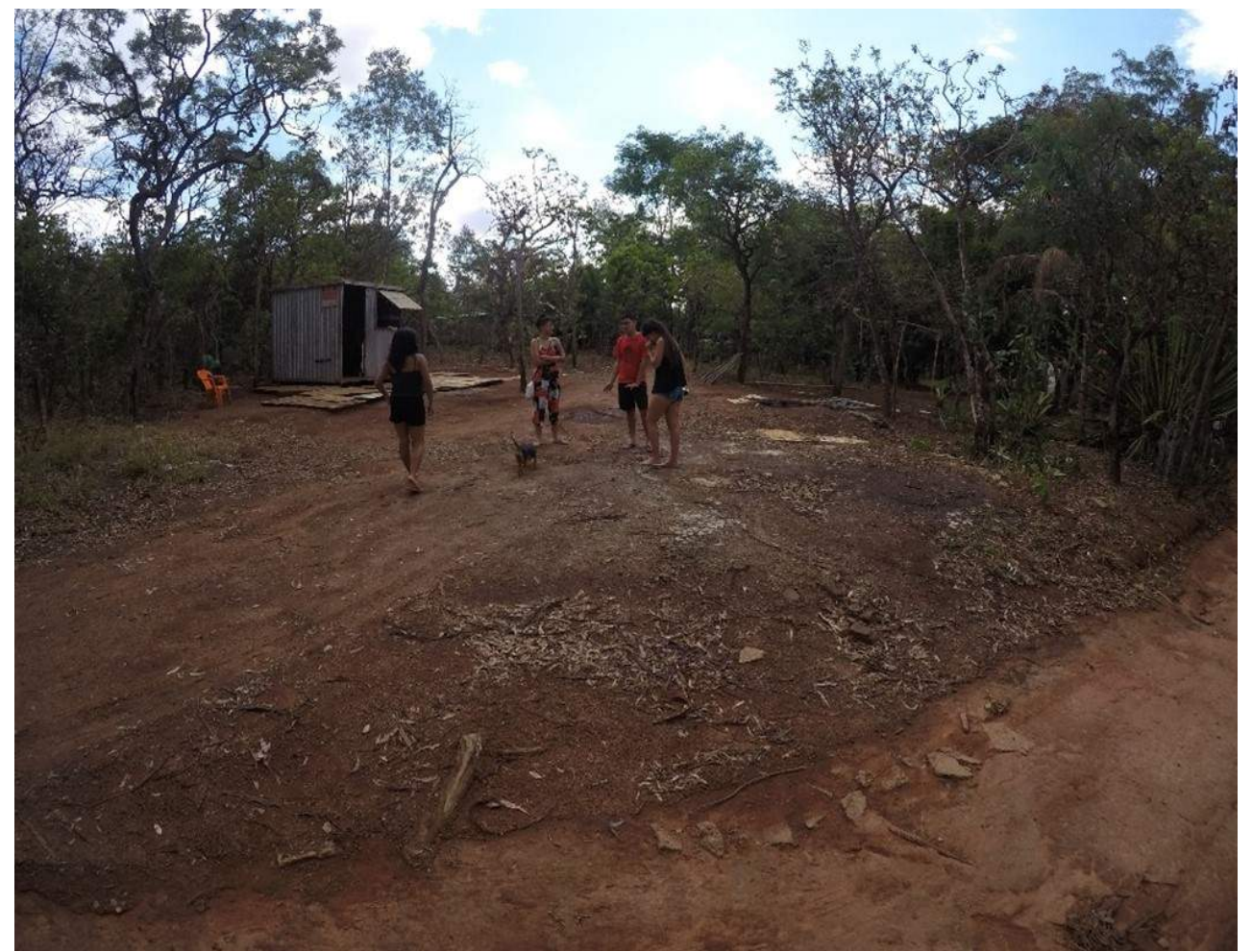

Fonte: acervo autores, 2020.

PatryTer | ISSN: 2595-0169 | vol. 4 | n. 8 | setembro 2021 | pp. 36-55 | Artigo 
habitações e onde, inclusive, veio a nascer a primeira criança indígena no Santuário Sagrado dos Pajés; um eterno e transcendental de-morar-se sobre a terra (Scarlato \& Costa, 2017).

A paisagem que envolve o Noroeste e o Santuário Sagrado dos Pajés é contrastante em muitos aspectos, dentre os quais as edificações: o primeiro busca imprimir em suas formas a continuidade moderna, modernista e modernizante da Brasília Heterotópica (Costa \& Alvarado-Sizzo, 2019), enquanto a comunidade indígena é composta por habitações mais simples no que diz respeito a sua forma, enquanto seu conteúdo é carregado de simbolismos e significados, como o Ministério do Índio Espiritual (fig. 9), cuja importância não se limita à estrutura física, mas em especial ao significado que exerce para a comunidade: fora a casa onde viveu o Pajé Santxiê, fundador do Santuário dos Pajés e onde veio a falecer, por conta do contexto de pressão do mercado imobiliário e da violência empreendida contra a comunidade.

A síntese da relação entre o Noroeste e o Santuário dos Pajés materializa-se na fronteira estipulada e imposta à comunidade. Não compreendendo fronteiras e limites geométricos, os territórios indígenas dispõem-se originalmente às condições do ambiente e pela situação da comunidade, em prol de sua subsistência. Tal dinâmica é rompida desde o momento da invasão ao continente dos povos originários, fazendo com que ainda seja preciso disputar os últimos locais onde a natureza é próspera e onde podem, os indígenas, suprir suas necessidades de alimentação e de moradia (Krenak, 2019).

A fronteira imposta ao território indígena expressa-se por técnicas, temporalidades e perspectivas distintas a respeito do território. $\mathrm{O}$ resultado é o conflito, que se processou de maneira mais intensa quando da iminência de que o bairro ecológico erguido sobre vegetação de cerrado, nascentes e território indígena seria, para o gozo do Estado-mercado, enfim construído.

Frente ao risco de perda do território legitimamente ocupado e produzido, emergem dos indígenas uma proposta de demarcação do território em 50 hectares (fig. 10); demanda não atendida. Somente no ano de 2018, depois de resistência e organização em busca da demarcação da área, um acordo envolvendo as lideranças da comunidade, e órgãos institucionais como a Companhia Imobiliária de Brasília [TERRACAP], Fundação Nacional do Índio [FUNAI], Instituto do Meio Ambiente e dos Recursos Hídricos do Distrito Federal - Brasilia Ambiental [IBRAM] e Ministério Público Federal
[MPF], definindo a cada uma das partes direitos e deveres.

Dentre os principais pontos trazidos no acordo, está a delimitação da área indígena em aproximadamente 32,5 hectares (fig. 11), após os indígenas cederem parte dos 50 hectares antes requeridos. A disputa em torno das dimensões da área está relacionada em especial à Via W9: obra de infraestrutura viária em processo de construção que, pelo projeto inicial, se sobreporia à comunidade indígena. Ademais, há outros pontos abordados no acordo que suprimem do projeto Noroeste algumas quadras e a garantia de resguardo das edificações presentes na comunidade indígena contra estragos e danos potencialmente causados pelas obras da Via W9ii.

A apreensão de aspectos relacionados à ancestralidade e à essência do território, perpassa um entendimento de ordem metódica e metodológica que ressalte o protagonismo indígena, do ser indígena, e sua relação indissociável com o território (com a terra); também se faz proeminente o entendimento de que o debate territorial indígena e a manifestação de sua ancestralidade remontam a uma realidade complexa, que envolvem tempos, escalas e técnicas distintas, marcadas por leituras do espaço e do território que destoam de concepções que os entendem desde perspectivas racionalizantes e com fins a apropriação e ao lucro.

Da busca pelo entendimento totalizante do território com o intuito de apreender seus usos e funcionalidades, em especial as inviabilizadas historicamente por todo tipo de poder técnico, político e midiático, emerge a cartografia (fig. 12) com vias a espacializar as disparidades e as singularidades referentes ao território usado.

A operacionalização do conceito de território usado (Santos, 1994) permite a emergência na análise territorial dos usos e das funcionalidades referentes ao território indígena, por essência coletivo, no qual os encontros e os aconteceres desde o cotidiano na comunidade, remetem a vida que animam as formas, dando-lhes conteúdos, promovidos e estimulados pelas trocas e compartilhamentos entre os indígenas, de forma que seja necessário a proximidade, estar junto. No contexto da Covid-19, apreender possíveis alterações nas dinâmicas territoriais da comunidade de estudo, torna-se relevante para contribuir ao entendimento de como a pandemia se manifesta sobre os povos indígenas, o que será discutido desde a experiência empírica do Santuário Sagrado dos Pajés. 
Figura 9 - Ministério do Índio Espiritual

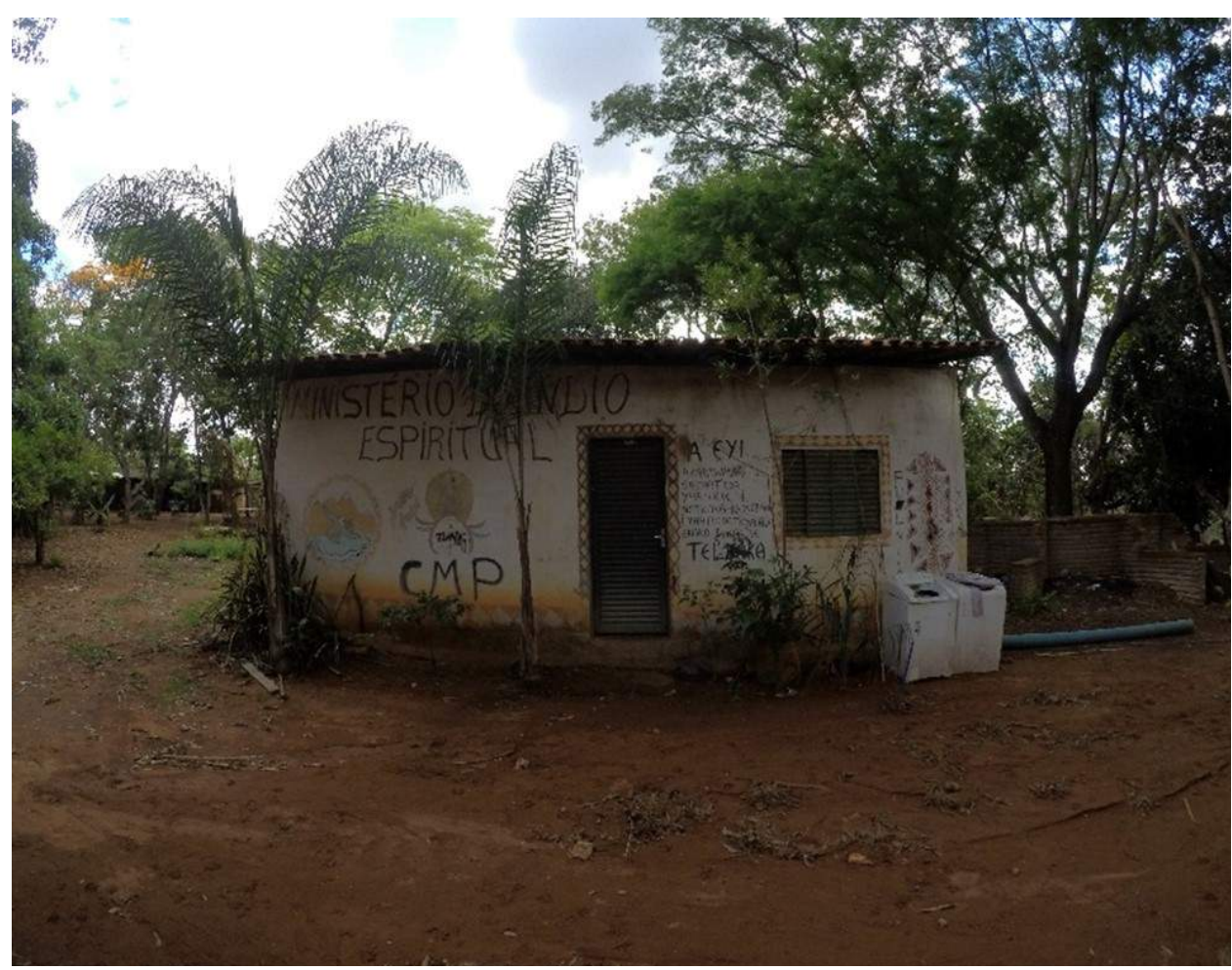

Fonte: acervo autores, 2020 .

Figura 10 - Proposta de demarcação - 50 hectares

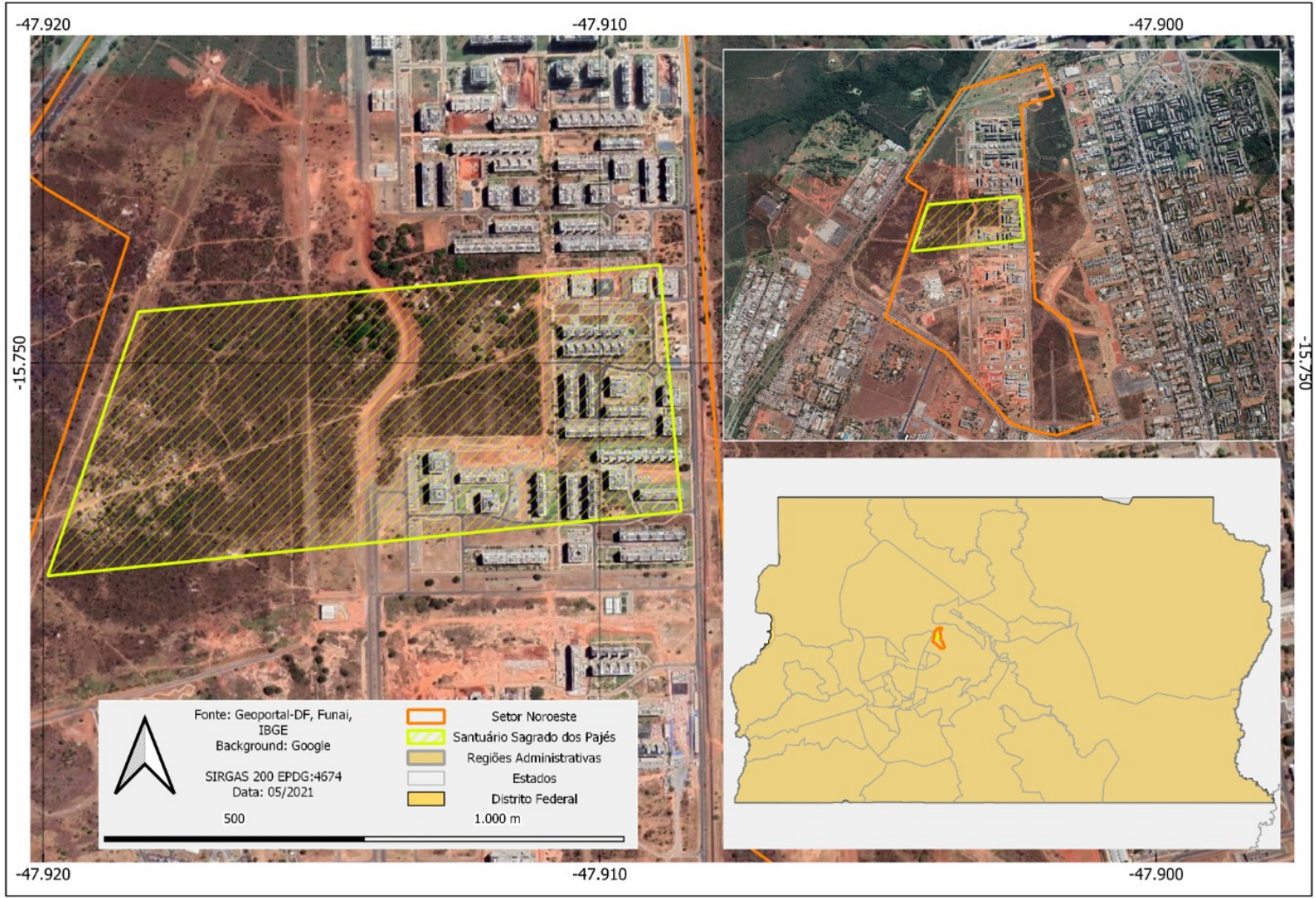

Fonte: elaboração própria, 2021. 
Figura 11 - Demarcação do território indígena em 32,4 hectares

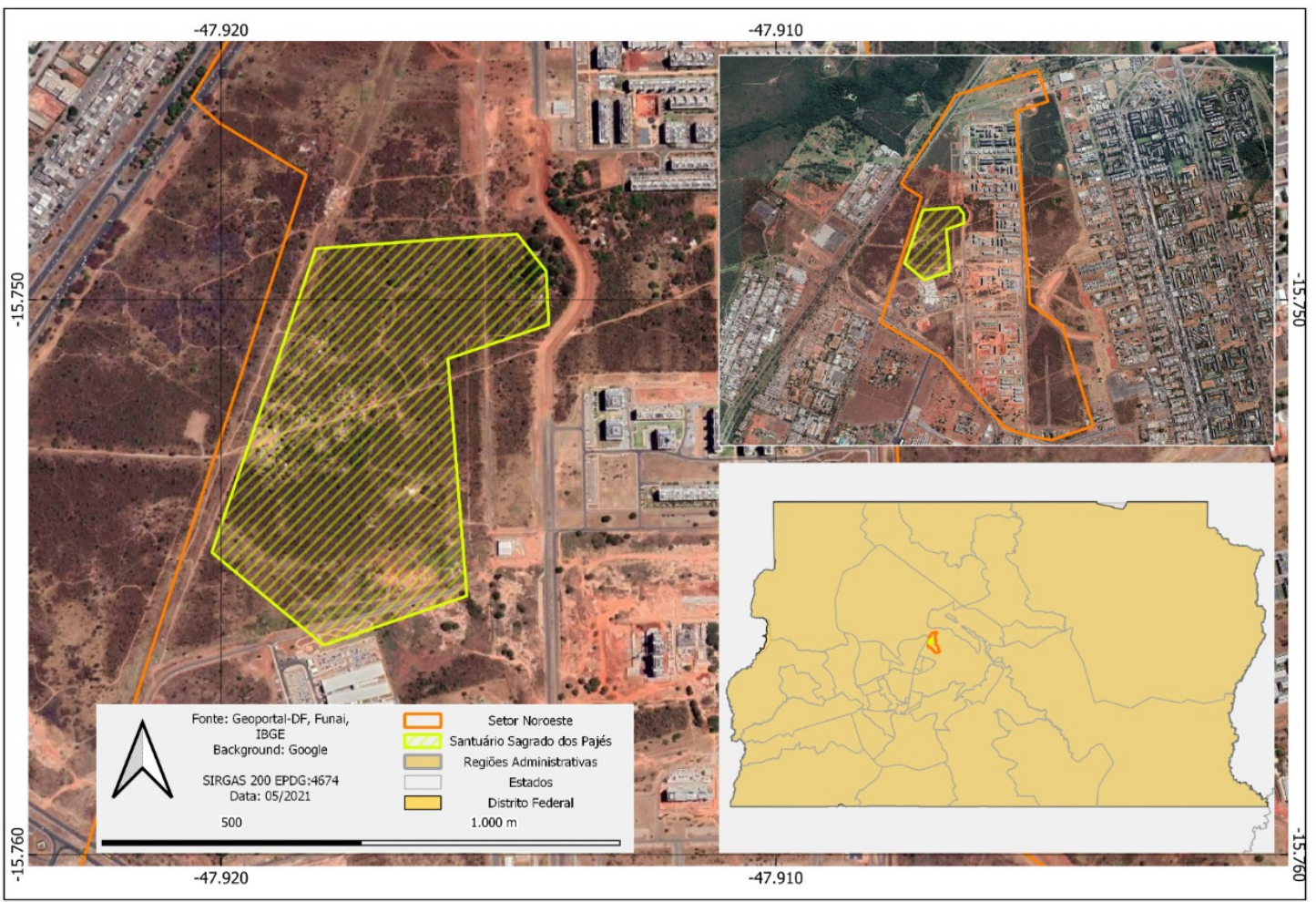

Fonte: elaboração própria, 2021.

Figura 12 - Usos e funcionalidades do território

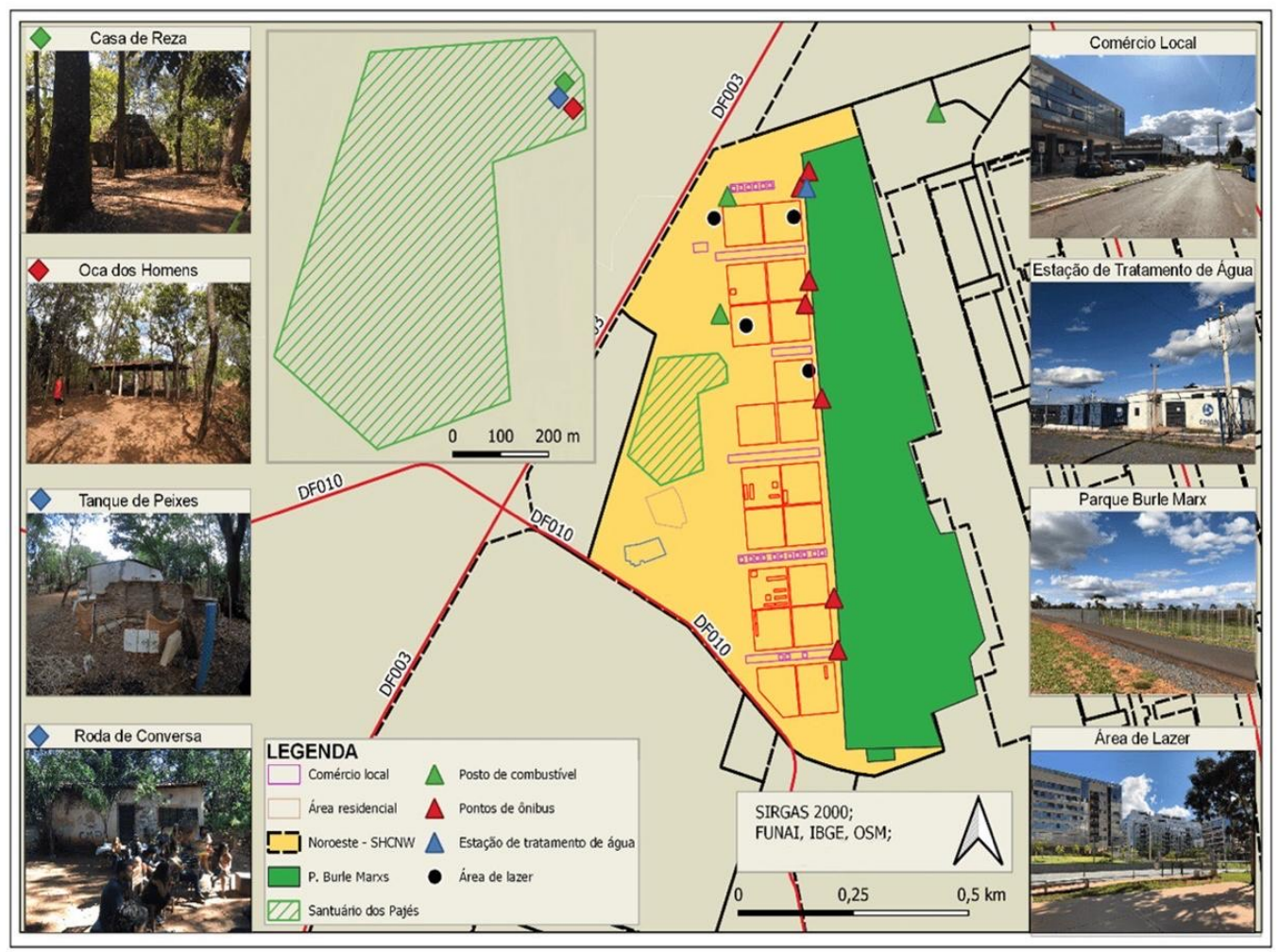

Fonte: elaboração própria, 2021. 


\section{As dinâmicas territoriais indígenas e a Covid-19}

No território do Santuário Sagrado dos Pajés processa-se uma dinâmica complexa. Frente a pandemia da Covid-19, cujos métodos de prevenção e controle de dispersão da doença envolvem medidas de isolamento e distanciamento social, cabe questionar, como as dinâmicas territoriais que se processam na área alteraram-se e quais seus efeitos sobre a comunidade indígena. Para tanto, fora realizada uma entrevista semiestruturada com a liderança jovem da comunidade, na qual foram abordadas questões referentes: 1. à infraestrutura de saneamento básico e habitação - e às relações que nelas se estabelecem -; 2. ao comportamento no ambiente doméstico e o contato com os parentes; 3. ao cotidiano da comunidade, isto é, às dinâmicas internas e externas a que está envolvida; 4. ao acesso a programas de atenção à saúde básica; 5 . ao acesso à informação e comunicação relacionadas a Covid19; 6. e à ocorrência ou não de casos positivos para Covid-19 na comunidade.

O caráter comunitário se expressa, entre outros, através da realização de rituais, encontros e rodas de conversas realizadas no território, envolvendo participação da comunidade e, a depender do teor e do conteúdo das práticas citadas, apoiadores indígenas de outras etnias e nãoindígenas. Nesse contexto, os rituais elaborados pela comunidade, realizados nas edificações presentes na área, foram comprometidos no que diz respeito ao caráter comunitário, tendo em vista o isolamento social; mas não deixaram de ser realizados, ficando restritos aos indígenas da mesma família e que habitam a mesma casa. Como nos fora relatado pela liderança da comunidade:

Em relação aos rituais tudo mais, teve um grande impacto principalmente na parte de se aglomerar, de não poder ficar próximo do parente, que no momento ali do ritual existe uma proximidade maior entre as pessoas entre os corpos, enfim [...] $e$ nós tivemos um ritual muito sagrado, que não pode ter outros parentes, então foi só a família aqui mesmo da casa da minha mãe que participon (Entrevista concedida pela liderança indígena FT, em Brasília, Distrito Federal, Brasil, em setembro de 2020).

As dinâmicas ritualísticas Fulni-ô extrapolam fronteiras e tempos, como o ritual do Ouricuri, realizado durante os meses de setembro, outubro e novembro, na aldeia do Ouricuri, localizada a cerca de $5 \mathrm{~km}$. do município de Águas Belas, cuja presença é de extrema importância para os indígenas Fulni-ô. Durante a vigência da pandemia, o que se sabe a respeito do deslocamento indígena ao Ouricuri, se limita ao que fora apreendido e relatado durante a entrevista semiestruturada que compõe o presente estudo, realizada virtualmente durante o período do ritual.

Ressalta-se que durante a permanência na aldeia do Ouricuri, uma série de restrições estão envolvidas, dentre as quais o uso de celulares; no entanto, há procedimentos inerentes ao ritual que permitem que em determinados momentos os indígenas se ausentem temporariamente da aldeia Ouricuri com destino à cidade, o que permitiu a realização da entrevista e quando nos foi informado que, do Santuário dos Pajés, houve o deslocamento de indígenas Fulni-ô à aldeia Ouricuri em Pernambuco. O que se sabe sobre o Ouricuri é pouco, tendo em vista que a participação neste e as próprias conversas a respeito do tema, se limitam aos indígenas Fulni-ô.

As mudanças no cotidiano da comunidade foram sentidas também em outros momentos de encontros e trocas:

Então, a gente sentiu sim impacto aqui, na mudança dos rituais, das nossas, por exemplo, rodas de conversas, fogueiras; essas coisas reduziram bastante; na verdade não estamos fazendo isso, fizemos a última vez há mais de um mês. É [...] também de ir à casa do outro parente, a gente também [...] reduziu bastante essas coisas aqui (Entrevista concedida pela liderança indígena FT, em Brasília, Distrito Federal, Brasil, em setembro de 2020).

Os aconteceres cotidianos acabam sendo fundamentais, tendo em vista que a apreensão da realidade se constrói desde o empírico: observando, escutando e dialogando, sem renunciar ao tato e a sensibilidade para compreender o que é dito e, também, o que não é dito. Afirma-se ainda, a relevância desses momentos de encontro e aproximação entre a comunidade indígena e nãoindígenas, apoiadores ou interessados em conhecer este constituinte do todo, como uma maneira de reverter o amplo discurso superficial a respeito das dinâmicas da comunidade indígena, vinculadas por diversos agentes e propagadas à sociedade. Nesses encontros são realizados debates sobre o processo de formação e consolidação da comunidade indígena, contação de histórias e cantos tradicionais (especialmente no dialeto que resguardam, o Yaathe), com a presença de escolas e universidades. 
$\mathrm{Na}$ vigência da pandemia da Covid-19, essas dinâmicas de visitas à comunidade foram, segundo relatado, uma das principais alterações sentidas:

Mudou mais no sentido de as pessoas entrarem aqui no santuário, que nós fechamos; fizemos uma barreira sanitária para o pessoal não ficar entrando: as pessoas que não são daqui, os não indigenas ou até mesmo outros parentes indigenas (Entrevista concedida pela liderança indígena FT, em Brasília, Distrito Federal, Brasil, em setembro de 2020).

Essas alterações nas visitas de apoiadores ao Santuário dos Pajés, interferiram na renda da comunidade. Apesar de alguns dos habitantes trabalharem fora do Santuário, a principal fonte de renda é obtida através da venda de artesanatos, constantemente disponíveis, mas sem compradores, resultando em um comprometimento da renda. Segundo foi relatado, o impedimento de receber apoiadores e visitantes acarretou:

Muito impacto, principalmente pelas pessoas que visitavam, que queriam visitar o Santuário, principalmente as escolas, as faculdades, que vinham muito; [...] principalmente nossa renda bruta, na verdade, ela vem através da venda de artesanato, das apresentacôes, enfim, dessas coisas. Então nós sentimos sim impacto, das pessoas não conseguirem vir, não poderem vir e tudo mais (Entrevista concedida pela liderança indígena FT, em Brasília, Distrito Federal, Brasil, em setembro de 2020).

A informação, segundo Santos (2014, p. 140), "joga um papel parecido àquele que, no passado remoto, era destinado a energia", elevando$a$ à função de reunir as diferentes porções territoriais. Segundo nos foi relatado, a principal fonte de informações a respeito da Covid-19 veio das redes sociais e de grupos de parentes em aplicativos de mensagens, compartilhando notícias, informações e a situação de outras comunidades. Além do mais, ressalta a disponibilidade de informações pelo Ambulatório de Saúde Indígena [ASI] do Hospital Universitário de Brasilia, o HUB:

Aqui em Brasilia foi muito via apoiadores que mandaram mensagem, o próprio ASI do UHB que entrou em contato [...] para ficar em observação com a gente, se tivemos algum contato com a covid ou alguma coisa assim. Tirando isso, a gente também colhe essas informacões do site da APIB [...], e páginas do Instagram [...] relacionadas ao movimento indígena. Acho que a gente não ouve muito jornal, a gente não segue muito jornal em si, [...] mas querendo ou não, uma bora ou outra nós ouvimos informações vindo jornal. Mas no mais veio a partir disso, do WhatsApp, outros familiares mandando informações[...] sobre covid, inclusive até mesmo como se proteger, como higienizar o alimento que compra no supermercado, o uso da máscara, foi muito via Whats App (Entrevista concedida pela liderança indígena FT, em Brasília, Distrito Federal, Brasil, em setembro de 2020).

O relato chama atenção para alguns aspectos: a questão da comunicação de massa, no caso, os telejornais, e a forma como as informações são difundidas e transmitidas, e o uso contrahegemônico das tecnologias atuais de comunicação nas redes sociais, cuja informação contida é dispersa em fluxos velozes e intermediadas por objetos técnicos cada vez mais racionais e intencionais, de forma que nessa "esfera da racionalidade hegemônica, pequena margem é deixada para a variedade, a criatividade, a espontaneidade" (Santos, 2001); mas das brechas deixadas emergem os usos contra-hegemônicos: as contra-racionalidades (Santos, 2006).

Pelo que foi exposto, a forma como a pandemia afeta e condiciona as dinâmicas territoriais da comunidade indígena em questão, definindo uma situação territorial que, apesar dos efeitos deletérios da Covid-19 sobre os modos de vida e organização de seus habitantes, delineia-se ao menos como favorável, ainda mais analisando-a no movimento de apreensão totalizante da situação indígena no Brasil durante esta pandemia, a qual segundo Krenak (2019), é um pedido de silêncio da Terra.

\section{Notas sobre a saúde indígena}

A busca do entendimento de aspectos relacionados ao acesso à saúde por parte dos indígenas habitantes do Santuário Sagrado dos Pajés e outros que habitam o Distrito Federal, perpassa a necessidade de que se compreendam questões históricas e atuais relacionadas ao tema. Assim, aponta-se como início das discussões referentes à assistência em saúde indígena através de missionários. Criado o Serviço de Proteção ao Índio (1910), a responsabilidade da questão coube a essa instituição de forma que, a partir de 1967, a atribuição é destinada a FUNAI. Em 1999, entrou 
em vigor a lei Arouca, a qual criou um subsistema de Atenção à Saúde Indígena; anteriormente, a questão era atribuição de vários órgãos, o que corroborou para irresponsabilidades do dever de instituir uma política efetiva para a estruturação do bem-estar indígena (Luna et al, 2020).

Pelo Projeto de Lei da Saúde do Indígena (de Sérgio Arouca) a responsabilidade da questão passou ao Sistema Único de Saúde [SUS] associado à Fundação Nacional da Saúde [FUNASA], órgão executivo do Ministério da Saúde, responsável pela gestão desse subsistema. Diante disso, tornou-se obrigatório levar em consideração a realidade local e as especificidades dos povos indígenas, contemplando a assistência à saúde, saneamento básico, nutrição, habitação, meio ambiente, demarcação de terras, educação sanitária e integração institucional (Fundação Nacional de Saúde, 2009).

Dentre as subunidades da FUNASA, destaca-se o Departamento de Saúde Indígena [DESAI], responsável pela gestão central do sistema e desenvolvimento de atividades implementadas pelos Distritos Sanitários Especiais Indígenas [DSEIS]. A DSEIS é um modelo de organização focado no espaço etnocultural do local de acordo com suas especificidades. Esse modelo de organização divide o modelo assistencial em um posto de saúde em cada comunidade indígena, um polo base, casa de saúde do índio e a algum hospital referência (FUNASA, 2009).

O Polo-Base é a primeira referência para os agentes de saúde que atuam nas aldeias. Nele, além da composição básica da Unidade Básica de Saúde [UBS], há o agente indígena de saúde [AIS]: habitante local treinado e capacitado pela FUNASA para atuar nos postos de saúde. Diante do desgaste e da crise da FUNASA, os povos indígenas reivindicaram maior autonomia na gestão da saúde, de forma que, em 2010, foi criada a Secretaria Especial de Saúde Indígena [SESAI], permitindo que todas as ações de saúde e saneamento básico nas comunidades indígenas fossem transferidas $\mathrm{da}$ FUNASA para o Ministério da Saúde, que terá como representante a SESAI (Lei n ${ }^{\circ}$ 12.314/2010, 20 de agosto, 2010).

No ano de 2013 foi criado o ASI do HUB fruto das reivindicações dos estudantes indígenas da UnB - em parceria entre a Universidade e a SESAI. $\mathrm{O}$ ambulatório atende indígenas referenciados pela CASAI de Brasília e estudantes indígenas da UnB, além de oferecer oportunidade para os estudantes indígenas atuarem como bolsistas do Programa de
Educação pelo Trabalho para a Saúde [PET-saúde] e participar da assistência aos indígenas no HUB.

Como nos foi relatado, o acesso à saúde por parte dos indígenas tanto do Santuário Sagrado dos Pajés, quanto a outros que vivem no Distrito Federal, se realiza majoritariamente através do ASI/HUB e de uma UBS:

Quanto ao acesso a saúde que nós temos, há o postinho aqui da 115[...] norte: ele nos recebe enquanto indígenas, moradores aqui do Noroeste, do Santuário especificadamente; e tem o HUB, que, como falei, é o ASI e o ambulatório indígena, que nos atendem para além do coviv-19. Nos atendem já faz. um tempo [...], nessa luta [...] dos centros indígenas, dos moradores indígenas do DF e das comunidades, das outras comunidades também, reivindicando esse espaço. Então nos recorremos muito ao $H U B$, até porque quando nós vamos em outros espaços e falamos que somos indígenas, já encaminham automaticamente para o HUB Entrevista concedida pela liderança indígena FT, em Brasília, Distrito Federal, Brasil, em setembro de 2020).

A discussão nos leva a indicar uma problemática referente a formação dos médicos, que durante a graduação, a priori, há pouca ou nenhuma experiência dos estudantes com aspectos tradicionais indígenas. A aproximação e imersão por meio de extensão universitária do estudante da saúde em comunidades e povos indígenas, poderia contribuir positivamente para a compreensão do conhecimento que estes povos detêm, uma vez que processos de saúde e doença envolvem formas diferentes, decorrentes das referências históricas, culturais e ancestrais desses povos, as quais devem ser respeitadas e conhecidas ${ }^{i i i}$.

Um interessante relato sobre esse aspecto foi transmitido quando questionamos o entrevistado sobre a ocorrência ou não de casos positivos para Covid-19 na comunidade indígena; ele no relatou:

Aqui não teve ninguém não, até porque a gente teve o alto cuidado da medicina tradicional: muito chá, muito banho, enfim, muito coisa de raiz assim, raizada, essas coisas. Também para se prevenir [...] nós usamos certas raizes, [...] certas folhagens e tudo mais, vindas de comunidades externas, por exemplo do Maranhão, Pernambuco e de outras (Entrevista concedida pela liderança indígena FT, em Brasília, Distrito Federal, Brasil, em setembro de 2020). 
Em Brasília, o ASI/HUB é um exemplo de extensão universitária, em que estudantes de saúde podem contribuir com o contexto de saúde indígena no Brasil. O PET-saúde do ASI é formado por três grupos: professores, preceptores - incluindo um pajé da etnia Tukano - e alunos, envolvendo diversos cursos de graduação (Hoefel, Severo, Díaz, Hamann \& Carvalho, 2015). No entanto, a extensão citada ocorre em apenas uma instituição de ensino; tendo em vista a amplitude de universidades e faculdades presentes no Distrito Federal, a ampliação de ações extensivas como do ASI/HUB poderia vir a contribuir com o aprendizado e a atenção à saúde indígena na região.

Apesar de toda a problemática nacional envolvendo a Covid-19 e os povos indígenas, processa-se na área uma realidade distinta, de forma que não houve, segundo nos foi relatado, nenhum caso de contaminação por corona vírus na comunidade:

Não, aqui no Santuário dos Pajés, dentro do território, falando de território, ninguém positivou por covid-19, não sei nas outras comunidades, mas aqui dentro do Santuário ninguém positivou. Eu tive sintomas, mas não foi covid, foram outras complicações, minhas mesmas, de saúde, [...] fiz. outros testes, fiz esse teste de covid e tudo mais, fui ao HUB, pelo ASI, inclusive (Entrevista concedida pela liderança indígena FT, em Brasília, Distrito Federal, Brasil, em setembro de 2020).

A realidade à qual nos referimos como sendo distinta, assim é considerada levando-se em consideração o relato de nosso entrevistado, quando questionado sobre apoios e ajudas recebidas no contexto da pandemia, ressaltando a importância e o papel positivo que os apoiadores e a $\mathrm{UnB}$ exercem na comunidade:

Então, a única instituição que está nos acompanhando, com a qual temos esse contato maior, é o HUB, mas especificadamente o ASI, que é o ambulatório de saúde indígena da UnB, que sobretudo foi uma luta dos centros indígenas com indígenas do DF em si; é o único que está nos atendendo assim, a quem podemos recorrer. As máscaras, por exemplo, que en recebi, que outros parentes receberam, foram de professores da UnB, de apoiadores que fizeram essas máscaras e deixaram aqui perto para irmos buscar, ou vinham deixar até mesmo próximo ao portão da entrada [...] seguindo todas as restrições: distanciamento social, álcool em gel [...], luva, máscara [...] então não teve contato próximo. Mas tirando o HUB não me recordo de mais ninguém que tentou nos ajudar aqui
(Entrevista concedida pela liderança indígena FT, em Brasilia, Distrito Federal, Brasil, em setembro de 2020).

Percebe-se através do que foi exposto, a complexidade que envolve as questões relacionadas à saúde indígena, marcadas "por ações esporádicas e abrangência irregular no território brasileiro" (Luna, Malvezzi, Teixeira, Almeida \& Bezerra, 2020, p. 2). Tratando-se de povos e comunidades indígenas, emerge a necessidade de apreender o território desde suas perspectivas, como uma instância indissociável do ser indígena, o que inclui os saberes e práticas milenares relacionadas a promoção de saúde e ao cuidado com seus corpos-territórios.

\section{Conclusão}

O contexto territorial em que a comunidade indígena Santuário Sagrado dos Pajés, em Brasília, está inserida, apresenta similitudes para com outras comunidades, não somente no Brasil, mas em todo o continente latino-americano: marcado por violências, ataques e depredações ao patrimônio e supressões de seus territórios ancestrais. Sobre tal cenário urge a necessidade de atuação com vias à supressão das mazelas históricas que os acometem. Para tanto, fazem-se indispensáveis estudos e conhecimentos empíricos da realidade, que se processam através da prática de campo e contato com a comunidade.

A situação da comunidade indígena de estudo, ademais dos efeitos nocivos da pandemia, como o comprometimento da renda mensal fruto dos artesanatos produzidos, possui aspectos considerados como favoráveis à contenção da pandemia da Covid-19 entre os indígenas que habitam o local. Destes cita-se: o contato que a comunidade possui com outras regiões do país, em especial em Águas Belas, Pernambuco, através do uso conta-hegemônico das técnicas de comunicação, favorecendo a troca de informações sobre a pandemia; a demarcação da terra - a despeito das críticas que podem e devem ser levantadas sobre tais processos de demarcação; as alterações das dinâmicas territoriais e ritualísticas da comunidade em prol do distanciamento social, confirmadas através dos relatos; e o acesso a sistemas de saúde especializados, ressaltando a relevância que a UnB exerce neste quesito. De forma conjunta, tais aspectos, analisados a partir de uma apreensão totalizante do território, defende-se, elevam o Santuário Sagrado dos Pajés a uma experiência empírica potencializadora de inversão da situação à qual os povos indígenas latinoamericanos estão inseridos. 


\section{Referências bibliográficas}

Alves, L. (2020). (Des)esperanças em tempos de pandemia: problematizações sobre a covid19 a partir da geografia crítica. Hygeia Revista Brasileira de Geografia Médica e da Saúde, 25-35.

https://doi.org/10.14393/Hygeia0054269

Articulação dos Povos Indígenas do Brasil [APIB] (2020). Emergência indigena: plano de enfrentamento da COVID-19 no Brasil. https://emergenciaindigena.apiboficial.org/ dados_covid19/.

Brayner, T. (2013). É terra indigena porque é sagrada: Santuário dos Pajés - Brasilia/DF. (Tese de Mestrado em Antropologia Social). Universidade de Brasília, Brasilia.

Coronavírus Brasil (2020). Painel Coronavírus. https://covid.saude.gov.br/.

Costa, E. \& Alvarado-Sizzo, I. (2019). Heterotopia patrimonial: concepto para estudios latinoamericanos. Scripta Nova. Revista Electrónica de Geografía y Ciencias Sociales, 23(620), 1-31.

https://doi.org/10.1344/sn2019.23.22329.

Costa, E. \& Scarlato, F. (2019). Geografía, método y singularidades revisadas en lo empírico. GEOUSP: Espaço E Tempo (Online), 23(3), 640-661.

https://doi.org/10.11606/issn.2179-

92.geousp.2019.161552.

Costa, E. \& Steinke, V. (2014). Brasília meta-síntese do poder no controle e articulação do territorio nacional. Scripta Nova. Revista Electrónica de Geografia y Ciencias sociales, 493(44), 1-27.

https://revistes.ub.edu/index.php/ScriptaN ova/article/view/15033/18385

Fundação Nacional de Saúde [FUNASA] (2009). Lei Arouca: a Funasa nos 10 anos de Saúde Indigena, 1-112. http://www.funasa.gov.br/site/wpcontent/files_mf/livro-lei-arouca-

10anos.pdf

Guimarães, R., Catão, R., Martinuci, O., Pugliesi, E. \& Matsumoto, P. (2020). O raciocinio geográfico e as chaves de leitura da Covid19 no território brasileiro. Estudos Avançados, 34(99), 119-140. https://doi.org/10.1590/s01034014.2020.3499.008.
Hoefel, M., Severo, D., Díaz, X., Hamann, E. \& Carvalho, H. (2015). PET-Saúde Indígena UnB: construindo redes interculturais em saúde. Revista Tempus: Actas de Saúde Coletiva, 9(1), 43-63.

http://www.tempusactas.unb.br/index.php/ tempus/article/view/1691/1398'

Krenak, A. (2019). Ideias para adiar o fim do mundo. Companhia das Letras.

Lei $\mathrm{n}^{\circ}$ 12.314/2010, 20 de agosto de 2010 (2010). Lei de criação da Secretaria Especial de Saúde Indígena é sancionada. Brasil. http://conselho.saude.gov.br/ultimas_notici as/2010/20_ago_lei_sesi.htm\#: :text=Foi $\% 20$ publicada $\% 2 \mathrm{C} \% 20$ nessa $\% 20$ sexta $\% 2$ Df eira,comunidades $\% 20 \mathrm{de} \% 20$ todo $\% 20 \mathrm{o} \% 20$ $\mathrm{Pa} \% \mathrm{C} 3 \% \mathrm{AD}$.

Luna, W., Malvezzi, C., Teixeira, K., Almeida, D. \& Bezerra, V. (2020). Identidade, Cuidado e Direitos: a Experiência das Rodas de Conversa sobre a Saúde dos Povos Indígenas. Revista Brasileira de Educação Médica, 44(2), 1-9.

https://doi.org/10.1590/1981-5271v44.220190309.

Mondardo, M. (2020). Povos indígenas e comunidades tradicionais em tempos de pandemia da Covid-19 no Brasil: estratégias de luta e r-existência. Finisterra, 55(115), 8188. https://doi.org/10.18055/Finis20364.

Moore, A. (2018). Repensar a escala como uma categoria geográfica: da análise para a prática. GEOgraphia, 42(20), 3-24. https://doi.org/10.22409/GEOgraphia2018 .v20i42.

Oliveira, J., Pereira, L. \& Barreto, L. (2011). Laudo Antropológico Referente à diligência técnica realizada em parte da área da antiga Fazenda Bananal, também conhecida como Santuário dos Pajés, localizada na cidade de Brasília, Distrito Federal, 1-49. https://www.academia.edu/23279098/2011 _Laudo_antropol\%CC3\%B3gico_de_natureza administrativa_sobre_a_Terra_Ind $\% \mathrm{C} 3 \% \mathrm{~A}$ Dgena_Santu $\%$ C3\%A1rio_dos_Paj $\%$ C3\%A 9s_em_Bras $\%$ C3\%ADlia_DF.

Rodrigues, A. (2012). La hegemonía del pensamiento neoliberal y el desarrollo sustentable. Scripta Nova. Revista Electrónica de Geografía y Ciencias Sociales, 16(418), 1-11. 
https://revistes.ub.edu/index.php/ScriptaN ova/article/view/14858/18033.

Santos, M. \& Silveira, M. (2008). O Brasil: Território e Sociedade no início do século XXI. Rio de Janeiro: Record.

Santos, M. (1994). O retorno do território. In M. Santos, M. Souza \& M. Silveira (Ed.). Território: globalização e fragmentação (pp. 1520). São Paulo: Anpur/Hucitec.

Santos, M. (2000). O papel ativo da geografia: um manifesto. Revista Território, 5(9), 103-109. http://www.ub.edu/geocrit/b3w-270.htm.

Santos, M. (2001). Por uma outra globalização: do pensamento único à consciência universal. Rio de Janeiro: Record.

Santos, M. (2006). A Natureza do Espaço: Técnica e Tempo, Razão e Emoção. São Paulo: Universidade de São Paulo.
Santos, M. (2014). Da Totalidade ao Lugar. São Paulo: Universidade de São Paulo.

Scarlato, F. \& Costa, E. (2017). A natureza do urbano. Confins. Revue franco-brésilienne de géographie, (30), 1-21. https://doi.org/10.4000/confins.11676.

Seima, M., Michel, T., Méier, M., Wall, M. \& Lenardt, M. (2011). A produção científica da enfermagem e a utilização da teoria de Madeleine Leininger: revisão integrativa 1985 - 2011. Escola Anna Nery, 15(4), 851$857 . \quad$ https://doi.org/10.1590/S141481452011000400027

Théry, H. (2020). Como o coronavírus viaja pelo Brasil, três casos exemplares. Confins. Revue franco-brésilienne de géographie, 45, 1-5. https://doi.org/10.4000/confins.28436

\section{Notas}

${ }^{i}$ Em 1956, se inicia o processo migratório com a chegada de 256 trabalhadores. Em janeiro de 1957, 2.500 trabalhadores e em julho do mesmo ano, 12.283 trabalhadores. Em março de 1958, 28 mil trabalhadores. A origem predominante dos Candangos eram os estados de Goiás (23\%), Minas Gerais (20,3\%) e Bahia (13,5\%).

iiAcordo judicial: 2009.34.00.038240-0 (ação civil pública). Disponível em: http://www.mpf.mp.br/regiao1/sala-deimprensa/noticias-r1/acordo-proposto-pelo-mpf-reconhece-terra-indigena-santuario-sagrado-dos-pajes-no-setornoroeste.

iiiA teoria da Diversidade e Universalidade do Cuidado Cultural (TDUC), proposta por Madeleine Leininge, engloba a visão de mundo dos indivíduos e as particularidades culturais e sociais no cuidado da doença e do bem-estar. Com essa teoria, busca-se agregar a cultura do indivíduo ao conhecimento científico da saúde (Seima, Michel, Méier, Wall \& Lenardt, 2011). 